$1-1-1976$

\title{
Public-supported transportation for rural areas : a study of Monongalia County, West Virginia.
}

Ernest J. Nesius

Follow this and additional works at: https://researchrepository.wvu.edu/ wv_agricultural_and_forestry_experiment_station_bulletins

\section{Digital Commons Citation}

Nesius, Ernest J., "Public-supported transportation for rural areas : a study of Monongalia County, West Virginia." (1976). West Virginia Agricultural and Forestry Experiment Station Bulletins. 647.

https://researchrepository.wvu.edu/wv_agricultural_and_forestry_experiment_station_bulletins/549 @ WVU. It has been accepted for inclusion in West Virginia Agricultural and Forestry Experiment Station Bulletins by an authorized administrator of The Research Repository @ WVU. For more information, please contact ian.harmon@mail.wvu.edu. 
ublic-supported ransportation for Rural Areas -

Study of Monongalia County, Nest Virginia

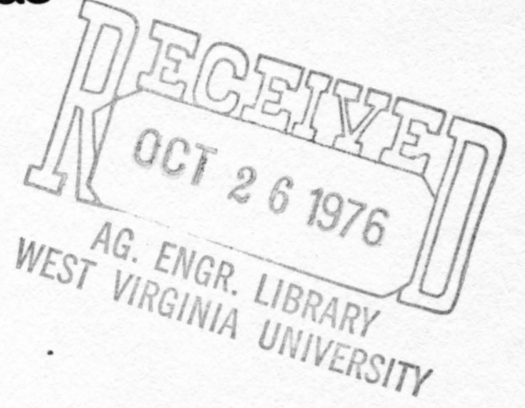

ulletin 647

eptember 1976

Vest Virginia University Agricultural and Forestry Experiment Station

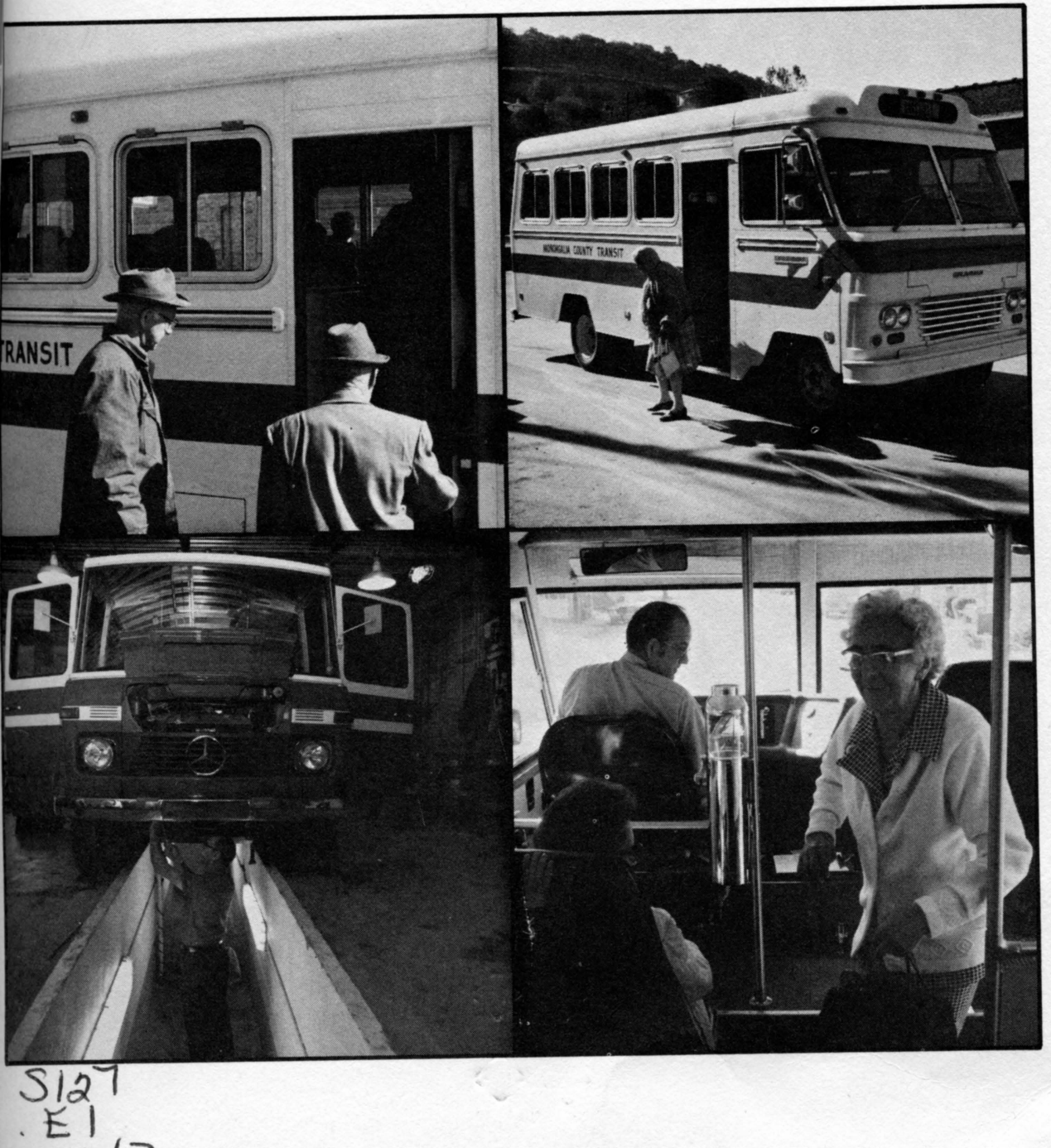




\title{
ABSTRACT
}

Personal interviews with 592 rural households of Monongalia County, West Virginia showed that 98 per cent consider availability of public transportation as important. Eighty-two per cent approved the use of public funds to support a rural transit system. One hundred thirty households had one or more members who sometimes rode the Monongalia County Transit Systems (MCTS). Approximately 60 per cent of the total cost was covered with public funds. The cost was $\$ 0.94$ per passenger and $\$ 0.66$ per mile given the conditions attendant to operation of the MCTS. It does not appear that private enterprise can meet needs of these rural households for public transportation.

Cost-benefit analysis showed that the benefits to rural residents greatly exceeded the costs, and resulted in an income redistribution from a relative few to the 900 estimated bus-riding households.

KEY WORDS: West Virginia, Monongalia County, rural transit system, rural households, elderly, low income, cost-benefit, county commissioners, revenue sharing, gasoline shortage, rural characteristics.

\section{AUTHOR}

Ernest J. Nesius is Benedum Professor of Agricultural Economics in the Division of Resource Management, College of Agriculture and Forestry; and Agricultural Economist in the West Virginia University Agricultural and Forestry Experiment Station.

\author{
West Virginia University \\ Agricultural and Forestry Experiment Station \\ College of Agriculture and Forestry \\ Dale W. Zinn, Director \\ Morgantown
}




\section{CONTENTS}

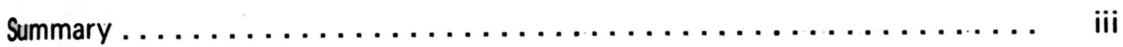

Introduction $\ldots \ldots \ldots \ldots \ldots \ldots \ldots \ldots \ldots \ldots \ldots \ldots \ldots \ldots \ldots \ldots, 1$

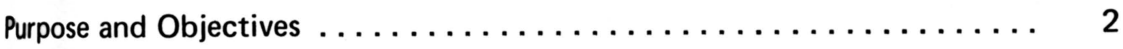

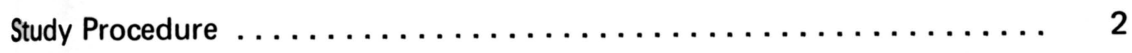

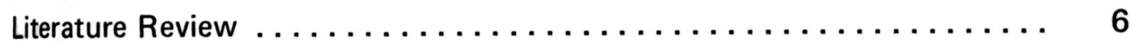

Location and Description of the Study Area ............... 9

The Monongalia County Transit System (MCTS) .............. 10

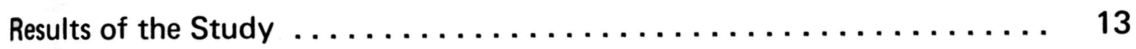

Impact of Gasoline Shortage $\ldots \ldots \ldots \ldots \ldots \ldots \ldots \ldots \ldots \ldots \ldots \ldots$

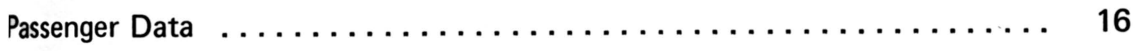

Annual Balance Sheet for the MCTS $1974 \ldots \ldots \ldots \ldots \ldots \ldots \ldots \ldots . . \ldots$

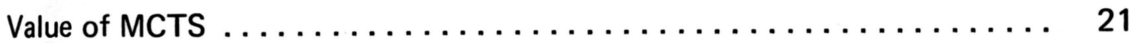

Distribution of Cash and Non-Cash Benefits ............... 24

Comparison on a Cash Basis...................... 24

Comparison When "Take Time" is Valued................ 26

Cost-Benefit Analysis . . . . . . . . . . . . . . . . . . 26

Prospective Routes Not Now Served $\ldots \ldots \ldots \ldots \ldots \ldots \ldots \ldots \ldots \ldots .29$

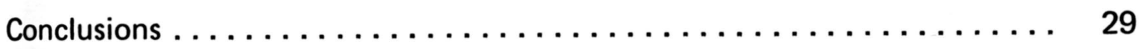

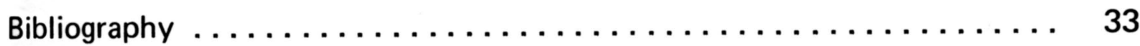

Appendix I. Social Rate of Return for MCTS over Seven Year Span ...... 34

Appendix II. Schedule of Bus Routes in $1974 \ldots \ldots \ldots \ldots \ldots \ldots \ldots \ldots 36$

Appendix III. Schedule - Part I, All Respondents ............. 37

Appendix IV. Schedule - Part IA, Roads Not Now Served .......... 39

Appendix V. Schedule - Part II, Bus Passengers .............. 41 
[Blank Page in Original Bulletin] 


\section{SUMMARY}

This study was made of a county-wide transportation system partially supported with public revenues. The purpose was to evaluate a system within a given combination of population density, income, and age distribution as related to revenue, social benefits and social costs.

The study area covered all of Monongalia County, West Virginia, except the county seat-Morgantown. The Monongalia County Transit System (MCTS) was established in April, 1973 with Revenue Sharing funds.

Interviews with 592 non-metropolitan households (16.3 per cent) residing within one-half mile of bus routes revealed that 82 per cent approved the use of public funds for the operation of the MCTS, and 98 per cent considered a rural transportation system important or very important.

In twenty-two per cent of the $\mathbf{5 9 2}$ households sampled one or more persons sometimes rode the bus with one-seventh of the bus-riding households indicating more than one member riding. Sixty-two per cent of the passengers were over 50 years of age.

The sample averaged 6.79 trips per month. The riders credited the MCTS with cash savings and income per month of $\$ 22.97$ per bus-riding household. An estimated 4,100 households and a total population of 12,957 persons lived within one-half mile of the seven bus routes. The total cash benefits accruing to the bus-riding households amounted to $\$ 248,196$. Of this amount, $\$ 106,143$ may be credited to the 35 full-time or part-time employees who credited the MCTS with the opportunity for employment. Total savings in transportation costs amounted to $\$ 138,472$.

A standard type cost and income statement for the MCTS showed an annual amortized capital cost of $\$ 11,572$ and an operating cost of $\$ 104,697-a$ total of $\$ 116,269$. Income from 127,925 passenger fares was $\$ 50,753$, with public funds of $\$ 65,516$ added to balance the account.

The annual operating cost of the MCTS were normalized and estimated to be $\$ 88,000$ for 127,925 passengers or $\$ 0.69$ per passenger or $\$ 0.4835$ for each of the 182,000 miles travelled. The total annual normalized cost was $\$ 119.704$ or $\$ 0.9357$ per passenger and $\$ 0.6577$ per mile.

A cost-benefit analysis was done to determine the present value of future benefits and costs using a 15 per cent discount rate. The ratio of costs to benefits exceeded the discount ratio by $\$ 2.95$ for each dollar expended. 


\section{[Blank Page in Original Bulletin]}




\section{Public-supported Transportation for Rural Areas-A Study of Monongalia County, West Virginia}

\section{Ernest J. Nesius}

With the increased comp!exities of modern living as a result of an increasing and a more urbaning population, transportation to central places has become a matter of considerable concern. Studies now show that the preference by families for living in the rural areas is increasing in some geographic rural areas, especially on the outward perimeters of cities and where agriculture is not a dominant source of livelihood. For such families, livelihood is dependent largely on urban employment or a retirement income. In these same areas many low income and the elderly families also are found. The latter families, as this study shows, need access to marketing and service centers.

As a general rule, the transportation problem is most severe where the countryside is dotted with dispersed households along the main roads and in small central places. ${ }^{1}$ Whether transportation wholly supported from private sources is economically feasible, depends largely upon some combination of population density, income level, and age distribution.

This study was made of a county-wide transportation system planned to serve rural households. The system was partially supported with public funds. In former years a privately operated system had discontinued service because it could no longer meet the economic requirements of income for maintenance and profit. This study, therefore, brings into focus the operation of a system within a given combination of population density, income, and age distribution as related to revenue, social benefits and social costs.

Passage of the Federal-Aid Highway Act of 1973 was one of the motivating factors prompting the study. In Section 147, funds are authorized for pilot transportation systems in rural areas. However, it was prior to passage of the Act that the Monongalia County Commissioners, based upon the expressed need of rural residents, did establish the Monongalia County Transit System (MCTS) with public funds to serve the rural areas and the municipalities adjoining Morgantown. It was believed that the experience of operating such a system would be of value to other counties in West Virginia and the nation.

${ }^{1}$ Populations of $100-2,000$ persons. "Central place" is the term which will be used generally throughout this report rather than attempting to describe and use such terms as stringtown, hamlet, village, town, urban area, or city. 
Within the period of this study, in February, 1974, a National strike by truck drivers coupled with an embargo on oil by the oil-suppling nations occurred. An indication of the impact on bus riders was reflected in the number of passengers, and is reported in this study. Such information should provide some indication of the impact of higher gasoline prices or gasoline rationing on the use of public transportation.

\section{PURPOSE AND OBJECTIVES}

The purpose of the study was to evaluate the economic and socio-economic factors as they have emerged in operating an existing public-supported transportation system established primarily for rural households. More specifically the objectives were:

1. Summarize and evaluate the lessons learned from one year's experience in operating a government-sponsored and operated rural transportation service.

2. Indicate and evaluate the major problem areas most likely to be confronted by county or regional authorities, as they might be concerned and must make decisions concerning a rural transportation service.

3. Estimate the costs and benefits resulting from this service.

4. Identify the rural characteristics which serve as indicators in selection of times and routes for a service after the decision has been made to establish a service.

Funds for this study were provided partially by the Rural Development Act of $1972 .^{2}$

\section{STUDY PROCEDURE}

Data for the study were obtained from the 1970 U.S. Census, especially for the enumeration districts, from randomly selected personal interviews, from the daily records kept by the MCTS supervisor, and from the financial records of the Sheriff's Office.

A random sample through personal interview of the households within what was considered as a reasonable distance from the seven established bus routes was decided as the best method. At the outset consideration was given to obtaining a random sample of only those that rode the bus. This proved to be almost impossible because of the differences in riders as related to hour, day, week, and month, all of which would be variables.

By choosing to random sample of the total population of the households neat the bus routes added the dimensions of opinion and evaluation by the

${ }^{2}$ Rural Development Act of 1972, U. S. Congress, Title V, provided funds and directions for research and extension participation. However, Experiment Station funds from federal and state sources were the principal source. 
households from which no persons rode the bus. This proved to add valuable insights for evaluating the system.

To determine whether distance from Morgantown was a factor in bus ridership, the county map was divided into four areas according to distance from the center of Morgantown. Area I included the municipalities adjoining Morgantown. ${ }^{3}$ Area II included the distance 31/2 miles from the City's center but beyond Area I. Area III included the distance between Area II and 5 $1 / 2$ miles from the Morgantown center. Area IV included the distance from Area III to the County line (see Figure 2).

Since the Monongalia County Transit System (MCTS) did not provide service to all sections of the county, a random sample by personal interview was taken of households on four roads leading to the established bus routes and on which the number of households were as frequent as on the regular routes.

To pre-test the schedules, interviews were taken from blocks one mile square as laid off on the county map. The pre-test showed that almost no potential bus riders go as far as a mile to catch the bus, even though passengers were picked up at any point along the route.

After the pre-test the county was then laid off in grids c.ne-half mile square. Only those blocks which were on or almost on the seven routes were considered eligible for the sample. For the four municipalities adjoining Morgantown, a city block was considered equivalent to a one-half-mile square block. A total of 348 blocks were eligible for sampling. For a block randomly chosen, each family residing in the block was interviewed. There were only very few refusals. The number of blocks sampled was determined to be between 16 and 18 per cent.

Methods of analyzing the data included: (a) cross classification determining simple averages for comparison; (b) traditional business accounting showing profits and losses; and (c) social benefit-cost accounting which measured relationships between the costs and social benefits. For the traditional business accounting, absolute data were used whereas adjustments were made for social benefit accounting to normalize the costs and benefits. Benefits measured were of two types: (1) savings io those persons riding the buses compared to alternate costs of transportation prior to establishment of the MCTS, and (2) income accruing to those persons indicating they would not be employed except for the existence of a public transportation system. The transfer of income and benefits from former recipients of iransportation income to the bus-riding households due to establishing the public transportation system was recognized but its impact was not extrapolated.

Three schedules were devised, one for all households sampled, one for households with one or more members riding the bus, and one for the interviews taken along the four roads not served by the MCTS. See Appendices III, IV, and

${ }^{3}$ Westover, Granville, Osage, and Star City. 
V. A total of 592 households were interviewed or an estimated 16.3 per cent of the non-metropolitan households residing within one-half mile of a bus route. Routes and blocks sampled are shown on Figure 2. In addition, 51 households were interviewed on the four roads not serviced.

To check the relationship of the sampled population to the county nonmetropolitan population two tests were made. ${ }^{4}$ The distribution of the population by age groups (Table 1 ) and the percentage of families in comparable income categories (Table 2) were related. In both comparisons the sample data are for 1974 while the enumeration data are for 1970 . Yet the relationships were quite similar.

A small bias towards youth shows in the enumeration district population due to the large number of West Virginia University students living in mobile homes outside the city limits of Morgantown. Otherwise the sample data are comparable, and thus indicate a high degree of representativeness.

\section{Table 1}

Comparison of Age Distribution for the 1974 Sampled Population with 1970 U.S. Census Enumeration Districts.

\begin{tabular}{lccc}
\hline Item & Unit & $\begin{array}{c}\text { Sampled } \\
\text { Households }\end{array}$ & $\begin{array}{c}\text { Enumeration } \\
\text { Districts }\end{array}$ \\
\hline Area & Number & 592 & 34 \\
$0-18$ yrs. & Per cent & 33 & 35 \\
$19-49$ yrs. & Per cent & 38 & 42 \\
$50-63$ yrs. & Per cent & 16 & 16 \\
65 and over & Per cent & 13 & 9 \\
Average number & & & $*$ \\
persons per family & & 3.14 & $*$
\end{tabular}

${ }^{*}$ Comparable data are not available. Informal calculations suggest approximately 3.25 .

${ }^{4}$ The non-metropolitan population represents all of Monongalia County exclusive of Morgantown. It does include four small municipalities adjoining Morgantown and another small one about $\mathbf{1 5}$ miles west. Data were obtained from the enumeration districts used for the 1970 U.S. Census. 
Figure 1. Enumeration Districts Used for the 1970 U.S. Census, Monongalia County, West Virginia.

G

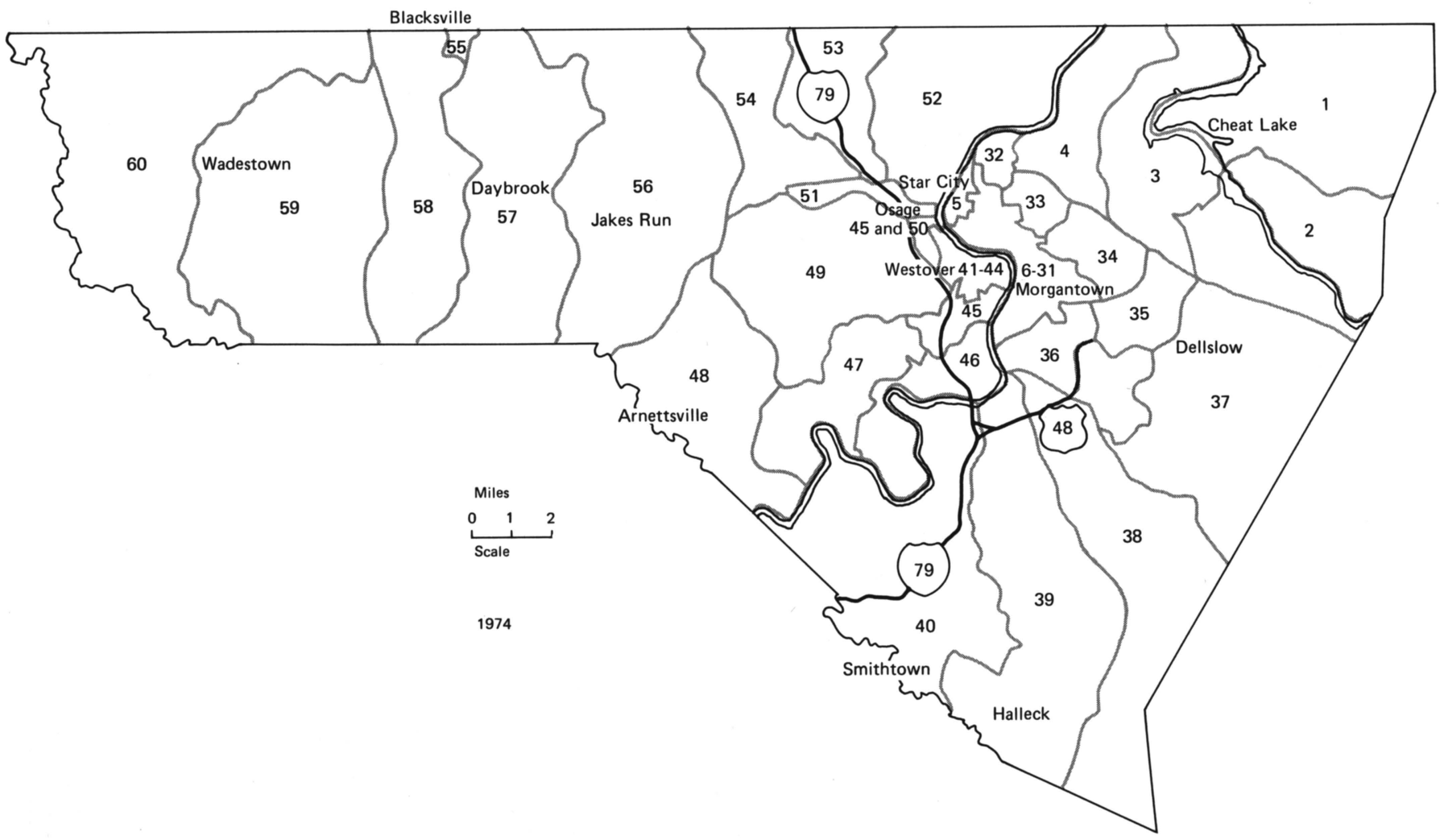


Table 2

Income Per Household for all Sampled Households (1974), the BusRiding Households (1974), and the Enumeration Districts (U. S. Census 1970).

\begin{tabular}{|c|c|c|c|}
\hline Income & $\begin{array}{c}\text { All Sampled } \\
\text { Households (592) }\end{array}$ & $\begin{array}{c}\text { Bus-riding } \\
\text { Households (130) }\end{array}$ & $\begin{array}{l}\text { Enumeration } \\
\text { Districts (34) } \\
\end{array}$ \\
\hline & $\%$ & $\%$ & $\%$ \\
\hline Less than $\$ 1,000$ & * & 1 & 3 \\
\hline$\$ 1,000-\quad 4,999$ & 22 & 38 & 25 \\
\hline$\$ 5,000-\quad 9,999$ & 57 & 45 & 45 \\
\hline$\$ 10,000-14,999$ & 17 & 13 & 19 \\
\hline Over $\quad \$ 15,000$ & 4 & 3 & 8 \\
\hline
\end{tabular}

${ }^{*}$ Negligible.

The income differences shown in Table 2 between all sampled households and the enumeration district households are minimal; however, the bus-riding households would be expected to have lower incomes as a higher proportion of them are elderly.

With strong indications that the sample of 592 households was a true sample of the households living within one-half mile of the bus routes, we may then extrapolate from the sampled population to the whole population. By counting the one-half mile blocks adjoining the bus routes it was then possible from the sample blocks to develop a ratio for estimating the total population. Using the ratio it was estimated a total of 4,100 households with a total population of 12,957 has access to the bus service. Of the 4,100 households, it was estimated that 900 had one or more persons who rode the bus. ${ }^{5}$

In the section "Results of the Study" the information reported follows closely the data as actually derived from the sample. In the section "Value of the Study" the results in appropriate places are extrapolated to the 4,100 households with access to the bus service.

\section{LITERATURE REVIEW}

The U.S. Rural Highway Public Transportation Demonstration Program was included in the Federal-Aid Highway Act in response to transportation needs in rural areas. 6

${ }^{5}$ The conversion figure in sample data multiplied by the factor 6.9257 .

${ }^{6}$ Section 147, Federal-Aid Highway Act of 1973: "To encourage the development, improvement, and use of public mass transportation of passengers within rural areas, in order to enhance access of rural populations to employment, health care, retail centers, education, and public services, there are authorized to be appropriated $\$ 30$ million for the 
The U.S. Secretary of Transportation investigated and reported findings on fifteen rural transit operations and management systems without the supporting data. ${ }^{7}$ The investigators chose fifteen for informal interviews out of a possible list of $\mathbf{5 5}$ passenger transportation systems provided by the Office of Economic Opportunity (OEO). All were in areas of low population density, and usually outside cities of 25,000 or more. Because the 55 projects were provided by the OEO, the implied assumption was that rural transportation systems were most needed for those households with low incomes.

The report emphasized that "need" expressed was greater than "demand" as those needing the transportation could hardly afford the usual transportation costs. The need for transportation, in general, was not to get to their place of work, which meant that the demand was irregular. Therefore, trips tended to be planned for obtaining one or more of various general services.

The investigators recommend starting the "service" small and expanding it as experience is gained and experimentation is tried. They suggest that probably the best way to "begin a rural transit is on the basis of providing service to the regular clients of social service agencies through contracts with those agencies."

The investigation also concluded that "fixed routes and schedules were desirable." Usually overhead costs were borne by the local Community Action Agency. Expected costs ranged from 10 to 20 cents per vehicle mile when administrative costs were not charged, and from 15 to 32 cents per vehicle mile when overhead costs were included. Most systems charged the users 2 to 5 cents per passenger mile.

Nearly all possible types of vehicles were used in the fifteen systems studied. Most typical was a 10-14-passenger van modified to provide headroom. The next most commonly found vehicle was a modified school bus. In other instances sedans and station wagons were used and in a very few instances urban transit type vehicles were used. Drivers for the vehicles varied from local volunteers to the regularly paid. As between types of systems found, multi-county (2-4 counties) and single county, the ratio was about one to one.

The report concludes, "In sum, this investigation provided no sound basis for confident conclusions about the continuing financial viability of rural transit."

2-fiscal-year period ending June 30, 1976, of which $\$ 20$ million shall be out of the Highway Trust Fund, to the Secretary of Transportation to carry out demonstration projects for public mass transportation on highways in rural areas. Projects eligible for Federal funds under this section shall include highway traffic control devices, the construction of passenger loading areas and facilities, including shelters, fringe and transportation corridor parking facilities to serve bus and other public mass transportation passengers, and the purchase of passenger equipment other than rolling stock for fixed rail."

${ }^{7}$ The Office of Policy and Plans Development. "Rural Transit Operations and Manage ment." A memo report, Secretary of Transportation, Washington, D.C. (Date was not given. Estimated in 1972 or 1973.) 
A study of particular interest to the present one was carried out using benefit-cost analysis in Raleigh County, West Virginia. ${ }^{8}$ The study compared the service and costs using a system of free minibuses operated by the local Community Action Agency with various alternative means of providind equivalent transportation. As a free transportation system, the income foregone may be considered as transfer payments to impact on income distribution because it utilized tax revenues in support of the socio-economic needs of the rural poor. On the other hand the cost was an unrealized loss of income or a disbenefit to the tax-paying public. Since the benefits and disbenefits, direct and indirect, are difficult to measure and evaluate, many economists are skeptical of imputing a quantified value to some social benefits such as a trip to the health center resulting in improved health. ${ }^{9}$

The Raleigh County free bus system consisted of 5 eight-passenger vehicles which covered most of the settled areas of the county each day. The buses were used by the passengers primarily for purchasing groceries, other shopping, attending community action meetings, and obtaining health care.

By calculating benefits and disbenefits, both direct and indirect, and by adding actual and imputed benefits and disbenefits and further to calculate the multiplier effects, the study concluded that for each dollar equivalent counted on the economic and social disbenefit side of the balance sheet, \$2.06 accrued as economic and social benefits. More important than the disbenefits, the study concludes, was the distribution of benefits, direct and indirect. The rural poor do not bear much of the cost of disbenefits therefore they were, in the main, the principal recipient of the benefits.

The study also considered the benefits and disbenefits of using various vehicles. Of those considered, the rank order of increasing costs per passenger mile were school buses 2 cents, mail vehicles 29 cents, larger buses (17-passenger) 31 cents, Jitney's 36 cents, used cars 40 cents, and surplus army jeeps 48 cents. Use of school buses and mail vehicles was considered impractical, if not impossible. Therefore, among the alternatives, the study concludes that the larger bus (17 passengers) would be the best choice.

A study by Shafran ${ }^{10}$ approaches the problem of transportation as it related to economic development. However, his study is only indirectly related to the

${ }^{8}$ Bureau of Public Roads. "The Transportation Needs of the Rural Poor." Research and Development Report, U.S. Department of Transportation, Washington, D.C. December, 1969.

${ }^{9}$ Actually the benefits, except for psychological values, are measurable if it is possible to obtain the needed data. For example, health care may affect the productivity of the individual or it may reduce the costs of health care, or further medical attention. Such data are difficult to obtain. Indirect benefits and secondary benefits are even more difficult to measure.

${ }^{10}$ Issac Shafran, "The Relationship Between the Structure of the Transportation Network and the Economic Development of West Virginia." Office of Research and Development, West Virginia University. Research Series 10, March, 1969. 
Monongalia County study. It concluded that major highways which intersect in relatively large isolated areas do in fact assist the economic development potential by attracting industries and improving "the market." When this happens the "need" and "demand" for public transportation from rural areas is significantly altered.

A review of the foregoing studies strongly suggests that public transportation systems for rural areas, dependent upon the existence of many factors, are primarily to meet the needs of low-income households, the elderly, and the handicapped. As a general statement, they are not a profitable venture for private ownership and management. Exceptions to these conclusions would be found in the more densely populated areas combined with a high proportion of employed residents and where there are difficulties associated with costs of traveling and downtown parking.

\section{LOCATION AND DESCRIPTION OF THE STUDY AREA}

The study area included all of Monongalia County, West Virginia, exclusive of the city of Morgantown, which has a public-supported system separate from the county system. The 1970 U.S. Census reported a population of 63,714 for Monongalia County. The population for Morgantown was reported to be 29,431. The four municipalities which adjoin Morgantown ${ }^{11}$ had a reported population of 7,403 , which when included with Morgantown adds to a total population of 36,834, which might be called "Greater Morgantown." However, the Morgantown Transit System does not provide service to the four adjoining municipalities. Another municipality of 264 persons when combined with the four municipalities ${ }^{12}$ and including Morgantown and subtracted from the total county population leaves 26,616 persons, who may be considered as living outside any municipality (an incorporated area).

On the Monongalia County Highway Map ${ }^{13}$ there are 66 named central places (Figure 1). Twenty-one have U. S. post offices. Population numbers are on record for 40 of the 66 . The MCTS serves all but 9 of the 40 . A tabulation by size intervals is shown on page 10 .

${ }^{11}$ Rural Development Act of 1972, U.S. Congress, Title V, provided funds and directions for research and extension participation. However, Experiment Station funds from federal and state sources were the principal sources.

12 Westover 4,747, Osage 614, Granville 806, and Star City 1,236.

${ }^{13}$ West Virginia Department of Highways General Highway Map, Monongalia County, West Virginia. January 1, 1972. 
Under 100

100 - 499

500 - 999

§,000 - 1,499

Over 1,500
6

24

5

3

2
15

60

12

8

5

With data provided for the enumeration districts ${ }^{14}$ (Figure 1) a general description of the characteristics of the non-metropolitan areas was determined. These are shown in Table 3.

Population density in the county varies greatly depending upon the degree of rurality or of urbanization, and the proximity to main roads. As shown in Table 3 , the total study area, which includes all of the county except Morgantown, has 93.2 persons per square mile. This figure contrasts with 4,393 for Morgantown.

\section{THE MONONGALIA COUNTY TRANSIT SYSTEM}

The decision to establish the Monongalia County Transit System was not based on a feasibility or other economic studies, but rather on the pressures brought to bear upon the elected County Commissioners to provide some form of public transportation services for the county residents.

The MCTS began operation in April, 1973. A privately owned and managed system service proved to be unprofitable. The city of Morgantown, using public funds, did establish a system, but only for the municipality.

Weekly discussions of the alternatives and a review of the operations of the Morgantown Municipal Transit System over a three-month period provided the needed information to initiate the MCTS. Major factors in the selection of vehicles were the roads and vehicle suitability for hilly terrain. For determining the routes, those developed by the former private system provided a beginning point. However, the eventual selection was determined largely by experimentation over the first eight months of operation. This led to considerable confusion as to time schedules and routes. To establish a charge for fares, the county was "zoned" according to distance from Morgantown. Three zones were set and fares for near Morgantown, the fare for one way was 40 cents; for intermediate distance, 50 cents; and farther out, 60 cents. ${ }^{15}$ Three tickets could be purchased at a 20 per cent discount. Student tickets were 25 cents for one way.

\footnotetext{
${ }^{14}$ U.S. Census, 1970.

${ }^{15}$ No established mileage was set, rather location of a central place was used as the break point.
} 
Table 3

Characteristic Data for the Study Area Compared to Monongalia County, Morgantown, and West Virginia

(U. S. Census 1970).

\begin{tabular}{|c|c|c|c|c|c|}
\hline & Unit & $\begin{array}{l}\text { Study } \\
\text { Area* }\end{array}$ & $\begin{array}{l}\text { Monongalia } \\
\text { County }\end{array}$ & Morgantown & $\begin{array}{c}\text { West } \\
\text { Virginia }\end{array}$ \\
\hline $\begin{array}{l}\text { Population density } \\
\text { per sq. mile }\end{array}$ & persons & 93.2 & 171 & 4,393 & 72.1 \\
\hline \multicolumn{6}{|l|}{ Population by residence } \\
\hline Urban & per cent & 15 & 54 & 100 & 39 \\
\hline Rural & per cent & 85 & 46 & - & 61 \\
\hline \multicolumn{6}{|l|}{ Income } \\
\hline Average per family & dollars & ** & 8,340 & 9,917 & 8,195 \\
\hline $\begin{array}{l}\text { Families below poverty } \\
\text { level }^{+}\end{array}$ & per cent & 14 & 13 & 12 & 18 \\
\hline \multicolumn{6}{|l|}{ Education } \\
\hline $\begin{array}{l}\text { Population enrolled in } \\
\text { school }\end{array}$ & per cent & 25 & 37 & 49 & 26 \\
\hline $\begin{array}{l}\text { Population working-age } \\
\text { group with } 9 \text { or more } \\
\text { years school }\end{array}$ & per cent & 78.3 & 53.9 & 73.2 & 41.6 \\
\hline $\begin{array}{l}\text { Population working-age } \\
\text { group with } 12 \text { or more } \\
\text { years school }{ }^{* *}\end{array}$ & per cent & 53 & 45.4 & 63.4 & 6.8 \\
\hline $\begin{array}{l}\text { Age Distribution } \\
55 \text { years or over }\end{array}$ & per cent & 18 & 18 & 16 & 22 \\
\hline
\end{tabular}

*The study area includes all of the county except Morgantown obtained from enumeration district data.

** Comparable data were not obtained.

***For study area the age distribution was 25-54. For the other three columns, data for males 20-49 and females 15-44 were combined.

+Poverty as defined by the U.S. Census. "The poverty income cutoffs are revised annually to allow for changes in the cost of living as reflected in the Consumer Price Index. In 1969 , the poverty thresholds ranged from $\$ 1,487$ for a female unrelated individual 65 years old and over living on a farm to $\$ 6,116$ for a non farm family with a male head and seven or more persons. The average poverty threshold for a non farm family of four headed by a male was $\$ 3,745$.

"Poverty thresholds are computed on a national basis only. No attempt has been made to adjust these thresholds for regional, state, or other local variations in the cost of living (except for the farm-non farm differential described above.) For a detailed explanation of the poverty definition, see U. S. Bureau of the Census, Current Population Reports, Series P-23, No. 28, Revision in Poverty Statistics, 1959 to 1968." 
Figure 2. Monongalia County, West Virginia, MCTS routes, Sampled Blocks and the Four areas of Varied Distance from Morgantown.

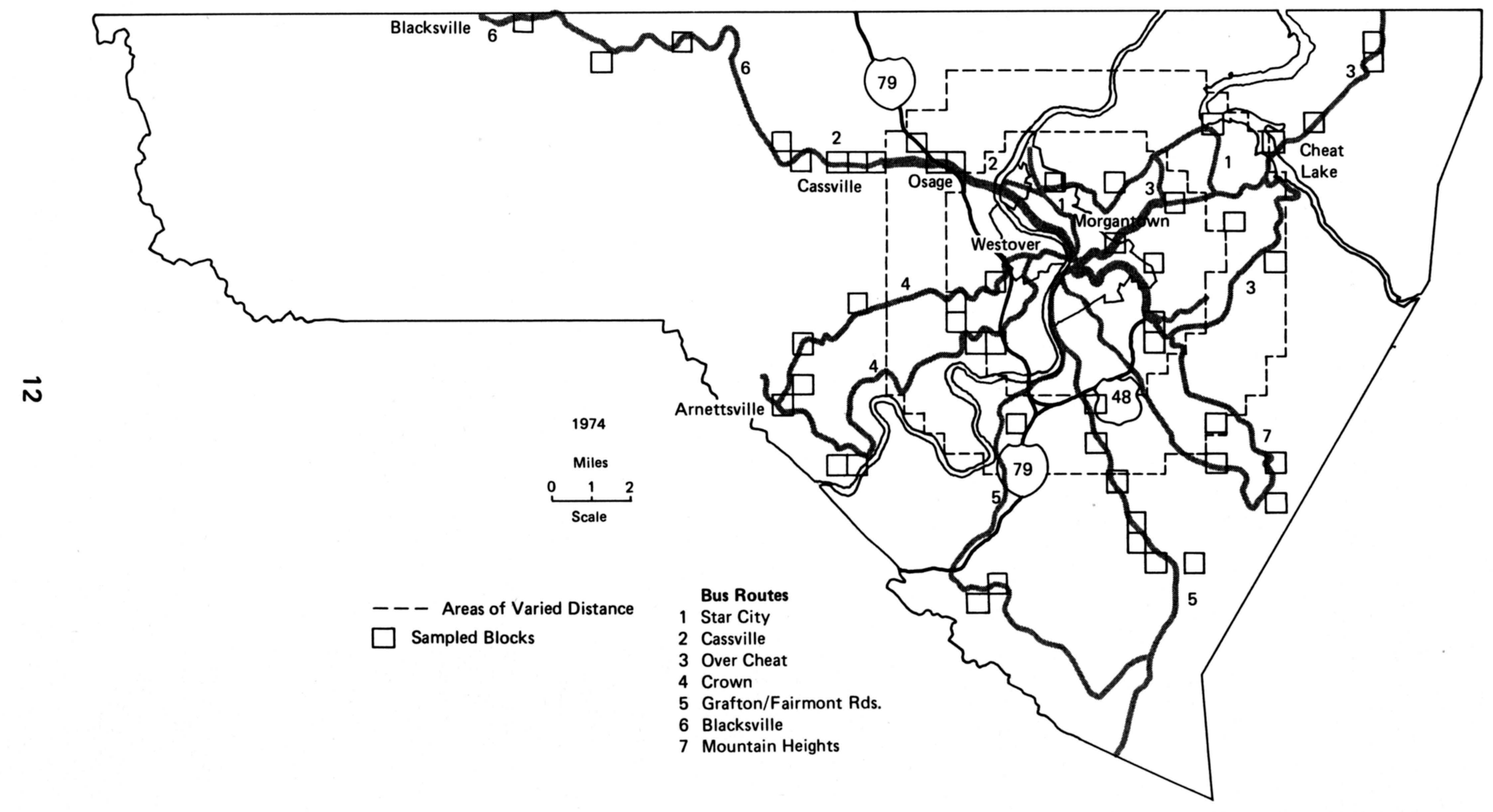


The essence of the problem as viewed by the County Commissioners was that the personal services needed by rural residents, and demanded, were to be found only in the metropolitan areas. Rural households with varying degrees of need were without access to them and, in some cases without employment. Discussions by the County Commissioners with their city counterparts resulted in finding no basis for a unified city-county transit system.

Fortunately, General Revenue Sharing Funds, ${ }^{16}$ proposed for 5 years, provided the capital for the initial investment, as the regular tax revenues were insufficient to cover the original cost. The Commissioners agree that without the Revenue Sharing Funds the MCTS probably would not have been started.

As the Commissioners reflect on their earlier decisions and the information available to them at that time, they conclude that, faced with the same circumstances, they probably would be more deliberate and require more studied information. However, they also feel that the pressures for assistance might require the same expediency as was evident in early 1973.

The original rolling stock consisted of 2 buses with 16-passenger capacity, 3 with 20 , and 1 with $33 .{ }^{17}$ In addition, a 14-passenger van was used for emergency purposes. Seven routes were established (see Figure 2).

Management of the MCTS was carried out by the County Commissioners and their staff. However, they hope to establish a transit authority, perhaps on a regional basis. The accounting system was carried out in the Sheriff's Office.

As to the legal authority for a county to operate a public transit system, the West Virginia Code does not explicitly forbid counties to operate public corporations, therefore, the authority is assumed to be implied. As a public-operated system the MCTS does not come under the regulations of the Public Service Commission.

\section{RESULTS OF THE STUDY}

General observations made by and about the total population sampled are reported first as descriptive data reflecting all households.

The average distance of the sampled households from a bus route was 216 yards, ranging from in front of the house to about one mile. ${ }^{18}$ Less than 1 per cent of the households were more than one-half mile from a route. A small bias in the study is to be found here due to the one-half-mile restriction in sampling procedure, however, the cost of sampling to obtain the few additional riders would have been excessive.

${ }^{16}$ The State and Local Fiscal Assistance Act of 1972 (Public Law 92-512).

${ }^{17}$ All these were Mercedes-Benz vehicles.

${ }^{18}$ In isolated instances due to the shape and the angling direction of the road a household might be one mile from the bus route. All sample blocks were square and the lines North, South, etc. 
Data were obtained to compare non-riders and riders. The average number of vehicles for all households was 1.55 . For the 130 bus-riding households, or 23 per cent of all sampled, the average number of vehicles was .58, and 1.71 for the non-bus-riding households.

The principal reason given by the non-bus-riding households for not using the MCTS (73\%) was access to their own or other means of transportation. The second reason of some importance $(9 \%)$ was that the bus schedule did not conform to their need for departure and return. ${ }^{19,20}$

All non-riding respondents were asked under what conditions they would ride the bus. The largest number, 42 per cent, said they would ride if other means of transportation were not available. Many didn't know. Of the additional respondents providing an answer, the three most typical conditions under which they would ride a bus related to high gasoline prices or its scarcity, the bus schedules corresponding to their needs, or an emergency when other vehicles were not available.

Because the MCTS is subsidized with public funds and operated with the policies and management of the County Commissioners, the opinion of all respondents was requested as to the appropriateness of using public funds for a county-wide transportation system. ${ }^{21}$ Eighty-two per cent of all respondents approved the use of public funds for the operation of the MCTS, with 7 per cent disagreeing, and 18 per cent with no opinion or comment. The reasons for their responses are shown in Table 4 .

\section{Table 4}

\section{Reasons Given as to the Appropriateness or Non-appropriateness of Using Public Funds for the MCTS.}

Provides a needed service for senior citizens

County funds should be spent to benefit the entire county

Rural residents can see where their tax money is spent

${ }^{19}$ Discussions with the supervisor of the MCTS indicated that there were too few riders to meet 8:00 a.m. or even 9:00 a.m. office starting times on all seven routes. Furthermore, there were not enough vehicles to meet all such schedules.

${ }^{20}$ Various other reasons of lesser importance were given for not riding the bus, such as the ride was too rough, etc.

${ }^{21}$ It should be stated that the County Commissioners would prefer a separate transit authority, however, the additional costs and Public Service Commission regulations, in their judgment, make such administrative management infeasible. Furthermore, they are on record as stating they would prefer a privately supported system. 


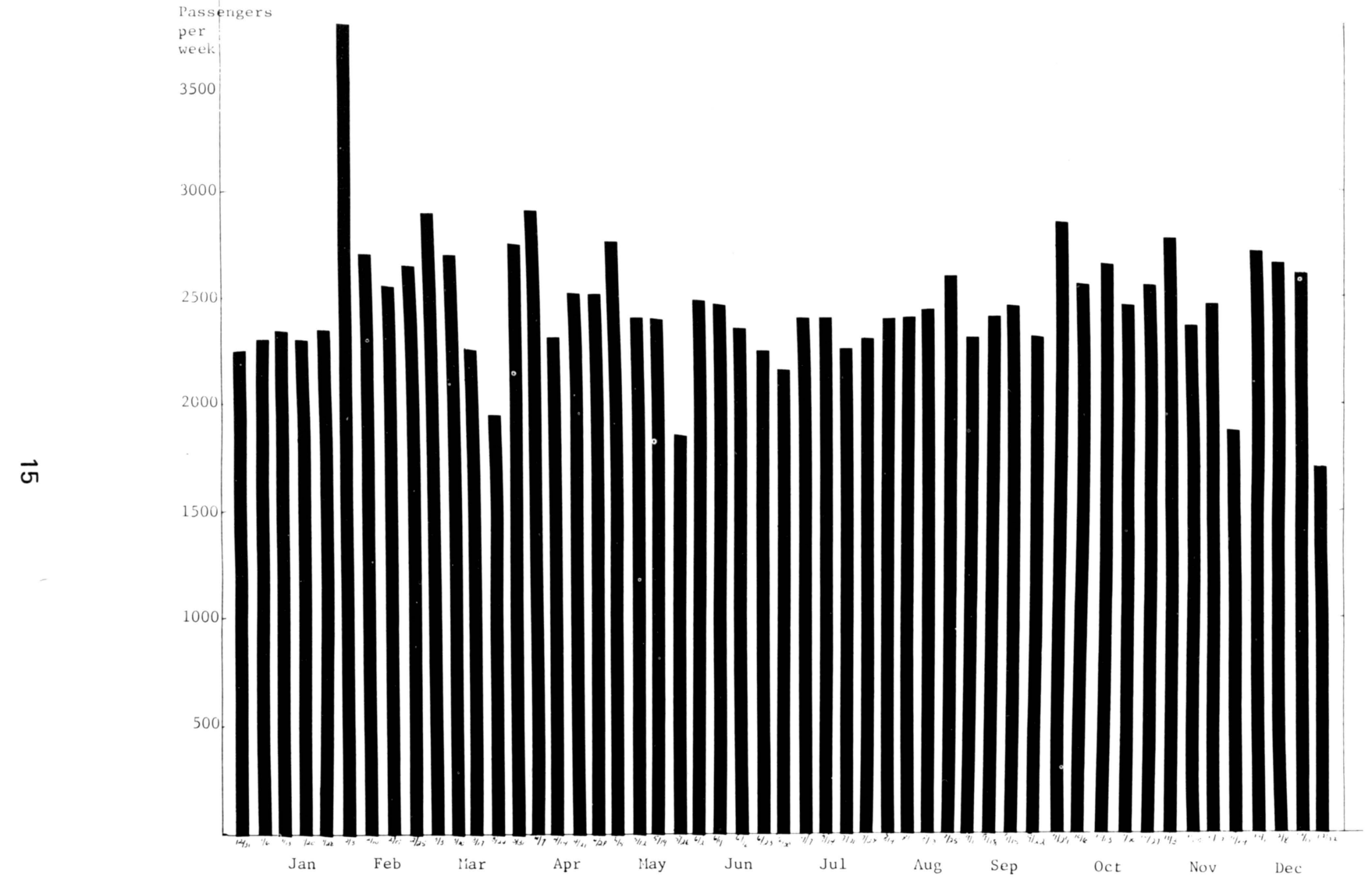

Figure 3. Number of Passengers by Six-Day Weeks-Monongalia County Transit System, 1974 
Throughout the interviews with respondents on related questions, the needs of senior citizens were recognized. The high per cent (30) favoring the use of public funds for the MCTS because it provided a needed service to senior citizens is testimony to their concern. The reasons for their concern were not solicited or evaluated. It was obvious also that rural residents feel that the taxes they pay must yield some service to them. The answers demonstrate that many of the respondents were not aware of the source of public funds, which were from federal sources. The data suggest that respondents assume the funds must have come from their taxes paid to the County.

When asked about the importance of the MCTS to the County, 98 per cent of the respondents considered it important or very important. Eighty-two per cent said it was needed for the elderly people with low incomes, and non-drivers; 4 per cent indicated that it was "good to know" that a means of transportation was available if needed; 2 per cent noted the convenience of the system (no concern with traffic or parking); and 12 per cent reported various unclassified reasons.

\section{Impact of Gasoline Shortage}

From the daily passenger records one can observe the impact of a gasoline shortage due to truckers' strike (Figure 3). The average number of riders over a six-day week for the four-week period prior to February 3, 1974, was 2,351 with a weekly range of 2,304 to 2,386. During the week of February 3 the number of riders increased to 3,786, 59 per cent over the previous week, and 61 per cent over the average of the previous four-week period. During the four weeks following the February 3 week the average number of riders was 2,669, a drop of $1,117(30 \%)$ riders per week. During the peak period bus drivers reported instances of standing room only, and the MCTS supervisor ordered additional bus runs.

\section{Passenger Data}

As reported earlier, the County maintained a regular schedule (see Appendix II) over seven routes, Figure 2. The MCTS supervisor maintained a complete daily record for each bus, each route, the time of day for passenger pick-ups, and the number of milesdriven. In this study such a volume of data presented an opportunity for more analysis than was considered essential to the objectives of this study.

The distribution of passengers by week, presented in Figure 3, shows a fairly consistent weekly average once allowance is made for holidays, first of month pay checks, and the unusual gasoline supply situation in February. The average for 1974 was 2,460 fares per week. The management of the MCTS estimated that a weekly average of 3,000 fares would be needed for the income to equal variable (operating) costs. However, the actual data did not bear out this 
estimate. The operating costs were higher than anticipated. Data for this study showed that between 3,700 and 4,000 fares per week would be needed to cover operating costs. Vehicle maintenance and repair costs were high due in part to the rough roads and in part to the high cost of foreign-made replacement parts. Miles covered per week by all buses averaged 3,500 .

More passengers ride in the afternoon (58\%) than in the morning $(42 \%)$. Reasonable conjecture suggests that persons may ride in an automobile with a member of the family or friend in the morning and return by bus in the afternoon at a time more convenient to themselves.

Except for the influence attributable to extra trips at the first of the month and low ridership on Saturdays, the daily ridership didn't vary much. The totals for the year showed that the most passengers rode the bus on Wednesdays and Fridays. About the same number rode on Mondays, Tuesdays, with fewer on Thursdays. Total fares by days are shown in Table 5 . The overall average was 410 per day.

Twenty-two per cent of the $\mathbf{5 9 2}$ households sampled had one or more persons who sometimes rode the bus, with 14 per cent of the bus-riding households indicating more than one member riding.

As shown in other studies and as was expected in this study, most of the persons who rode the bus were in the older age categories (Table 6). Sixty-two per cent of those riding the bus were over 50 years of age, compared with $\mathbf{3 6}$ per cent of all the persons residing in the same households. These data compare to 25 per cent for the households in the study area (Table 1).

\section{Table 5}

Average Fares By Days of the Week, MCTS, 1974.

\begin{tabular}{lcc}
\hline Day & Fares Per Day & Per cent of Total Fares per Week \\
\hline Monday & 423 & 17.1 \\
Tuesday & 422 & 17.1 \\
Wednesday & 452 & 18.4 \\
Thursday & 391 & 15.9 \\
Friday & 443 & 18.1 \\
Saturday & 330 & 13.4 \\
Daily Average & 410 & \\
\hline
\end{tabular}


Table 6

Age Distribution of the Members of Households from which One or More Rode the MCTS Compared with the Age Distribution of the Persons Actually Riding, 1974.

\begin{tabular}{lcc}
\hline $\begin{array}{c}\text { Age } \\
\text { Interval }\end{array}$ & $\begin{array}{c}\text { Households with } \\
\text { Member(s) Riding MCTS }\end{array}$ & $\begin{array}{c}\text { Persons Who } \\
\text { Rode the Bus }\end{array}$ \\
\hline & Per cent & Per cent \\
$0-18$ & 34 & 11 \\
$19-49$ & 30 & 27 \\
$50-64$ & 18 & 27 \\
65 and over & 18 & 35 \\
Over 50 & 36 & 62 \\
\hline
\end{tabular}

The incomes of the households with bus-riding members are shown in Table 2. The fact that the households with persons riding the buses were found to be in an older age category may also account for the higher per cent in the lower income category.

The bus-riding households reported an average of 6.79 trips per month with a range of 1 to 39 trips for one or more members. The stated purposes of the trips, almost always to Morgantown, are as follows:

Several purposes on each trip* 73

Employed in Morgantown or vicinity

Financial services

Health care

Varied other purposes**

*Shopping, health care, personal needs, and attended to financial matters.

**Visit Senior Center, relatives or friends, or for recreation, etc.

As would be expected, retired persons, service workers including domestics, and laborers, except farm, represent the largest percentage of the bus riders. If only one member of the household rode the bus, retired persons represented the largest group. If a second member also rode the bus, service workers or laborers dominated the list. In addition, a few were managers, clerical workers, and students (see Table 7). 


\section{Annual Balance Sheet for the MCTS}

The balance sheet set up in Table 8 treats MCTS as a private business. Depreciation costs and interest on investment are included.

\section{Table 7 \\ Occupations of Households in Which One or More Rode the MCTS, 1974.}

Number

Service worker (include domestic)

Laborers (except farm)

$14 \%$

$21 \%$

Unemployed

Retired

Craftsman, operations, (include transport)

$10 \%$

Miscellaneous

\section{Table 8}

\section{Annual Income and Expenses for MCTS, 1974 Only.}

\section{Item}

Amount

Capital Cost*

$\$ 11,572$

Operating Cost **

Total Cost

$\$ 116,269$

Income from fares

50,753

Annual loss

Total

*Assumes seven years life for vehicles, repairs over life of vehicles equal to or original cost, and $\$ 3,000$ annual rental cost for use of garage. The original cost of the six vehicles was approximately $\$ 101,300$. Salvage value at the end of seven years was estimated at $\$ 21,600$. Interest was charged at $8 \frac{1}{2}$ per cent, which added an annual charge of $\$ 1,230$ to capital costs.

**Includes salaries, supplies, fuel, oil, vehicle maintenance, tool replacement, etc. 
Study of the balance sheet shown in Table 8 yields the generalization that about one-half the operating cost and all the capital costs must come from public funds for a system with the characteristics as shown in the following tabulation.

\section{Population Characteristics}

Population per square mile

Per cent of population over 50 years of age

$90-100$

Average household income (1970 base)

Per cent of families with incomes below poverty level

$\$ 8,000-10,000$

14-16

\section{Capital}

Six buses varying in capacity from 14 to 33 passengers

A garage large enough to carry out ordinary maintenance

A record keeping unit-probably at no extra cost if a public enterprise

\section{Operating}

Seven full-time staff members including a supervisor, drivers, and maintenance Fuel and repairs for 3,500 miles per week over primary and secondary roads A weekly passenger load of about 2,500 persons 22

Income of $\mathbf{4 0}$ cents per passenger fare

To determine normal operating costs some adjustment was necessary. Unusual expenses were experienced due to use of foreign-made vehicles for which replacement parts cost considerably more than comparable parts would cost for domestic vehicles. To obtain a normalized figure the costs per month were arrayed over a 24-month period and the average of the median four months was assumed to approximate a normal mainentance cost, which is probably on the low side. The adjusted annual operating cost of $\$ 88,000$ for 125,925 passengers calculates to be $\$ 0.66$ per passenger, whereas the actual income per passenger was $\$ 0.3967$. Total annual mileage for all buses was 182,000 at an operating cost of $\$ 0.4835$ per mile, capital costs omitted. When capital costs are included, the total cost would be $\$ 119,704$, or $\$ 0.9357$ per passenger and $\$ 0.6577$ per mile. (See Appendix I.)

Data were not available to determine the rider-demand at variable costs for the fares; however, the fares appear low and could be probably increased some without a decline in the number of riders. See Table 9 for a passenger load needed to cover operating and total costs.

${ }^{22}$ Fares of 2,500 passengers per week fail to cover operating costs, but 3,700-4,000 fares (45 cents average) would. 


\section{Table 9}

\section{Number of Bus Riders Each Week Needed to Cover Operating and Total Costs at Variable Average One-Way Fares.}

\begin{tabular}{lcc}
\hline & \multicolumn{2}{c}{ Number of bus riders to cover costs } \\
\cline { 2 - 3 } Average all fares & Operating & Total \\
\hline \multirow{2}{*}{ cents } & 4,230 & 5,755 \\
45 cents & 3,760 & 5,115 \\
50 cents & 3,384 & 4,604 \\
\hline
\end{tabular}

The average number of passengers per week in 1974 was 2,460. The greatest number for any one week was 3,786 during the week of February 3 , when the truckers were on strike. If 3,786 passengers rode the bus each week, the cost structure would increase but not in the same proportion as the passenger increase due to the unused capacity found in the system in 1974.

In strict cash income and expense accounting the MCTS operates at a substantial annual loss $(\$ 65,516)$. This is offset by a subsidy by the County. ${ }^{23}$ However, there are substantial cash and non-cash benefits which accrue to the riders, and to those friends, relatives, or family members who otherwise would be required to transport them. Therefore, a true comparison should consider these benefits in comparsion to the typical business statement of income and expenses. Three ways to make such comparison are shown in Tables 12, 13 and 14. Tables 8 and 11 provide the basic data for the comparison.

\section{Value of MCTS}

In absence of a transportation system for the persons needing transportation: 35 per cent used taxis; 25 per cent, a close friend or relative; 22 per cent, a member of the family; and 14 per cent, varied other means. ${ }^{24}$ Data are shown in Table 10.

Based upon the sample, the total annual cash benefits accruing to the 900 bus-riding households was $\$ 248,196$ (Table 11). Of this amount, $\$ 106,143$ can be credited to the estimated 34.6 employed, but usually part-time employees, who without the MCTS stated they could not get to their place of employment.

${ }^{23}$ From Table 5, total annual cost $\$ 116,269$ less income from fares $\$ 50,753$ or $\$ 65,516$.

From subsidies, interest and taxes are considered as transfer payments from one segment of the public to another and frequently are omitted as cost items in social accounting. However, the study here is addressed to local public decision-making bodies, and therefore they are included.

${ }^{24}$ Four of the 130 bus-riding households reported no other way. Neighbors apparently attended to their needs, and in effect they were immobile. 
Table 10

Means of Transportation Showing Number of Trips to Morgantown Each Month, and Estimated Cash Savings per Month Credited to the MCTS by Individual Households, 1974.

\begin{tabular}{lccc}
\hline Item & $\begin{array}{c}\text { Means Used Prior } \\
\text { to MCTS }\end{array}$ & $\begin{array}{c}\text { MCTS } \\
\text { From Sample }\end{array}$ & $\begin{array}{c}\text { Adjusted } \\
\text { MCTS* }\end{array}$ \\
\hline
\end{tabular}

\section{Used Taxi Service}

No. Households

No. Trips per Month

Cost per Month

Savings per Month
46

6.40

$\$ 29.88$

- -
46

7.24

$\$ 7.24$

$\$ 22.24$
46

7.24

$\$ 5.95$

$\$ 23.95$

\section{Depended on Close Friend or Pelative**}

No. Households

No. Trips per Month

Cost per Month***

33

7.13

$\$ 14.80$

Savings per Month

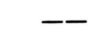

\section{Depended on Family Member**}

No. Households

29

No. Trips per Month

Cost per Month ${ }^{* *}$

$\$ 7.63$

Savings per Month

\section{Depended on Varied Means**}

No. Households

No. Trips per Month

Cost per Month ${ }^{* * *}$

Savings per Month

18

5.18
33

7.26

$\$ 7.71$

$\$ 7.09$
33

7.26

$\$ 5.98$

$\$ 8.82$

*The cost per month for riding the bus had to be adjusted downward because the extrapolated total revenue exceeded the actual by $\$ 14,622(\$ 65,375$ estimated less $\$ 50,753$ actual) or 22.37 per cent. The reasons for the larger extrapolated figure were: (1) round trip tickets were sold at a reduced price of 20 per cent and student tickets were sold for 25 cents. The enumerators found it almost impossible to obtain this information. The actual subsidy (reduced price) for both round trip and student tickets amounted to $\$ 6,569$ for 1974 . (2) one route, the Mountain Heights route (number 7 on Figure 1), was not started until June, 1974 and thus a per month figure distorted the total. (3) respondent error in reporting accounted for some because respondents wanted the MCTS to continue, answers tend to be as positive, and thus some bias. The adjusted data were derived from a constant percentage change and applied to dollar value only. The downward adjustment had the effect of increasing the amount of savings credited to the MCTS.

**Estimated amount and value of time given by friend, relative, member of family, or someone else not included here.

*** Cost of automobile was calculated at 15 cents per car-mile plus parking fee. 
Cash transportation savings to the remaining 865 bus-riding households amounted to $\$ 138,472$. The remaining $\$ 3,580$ was saved through various but less important reasons.

Other types of savings were credited to the MCTS. For example, one household eliminated a vehicle. A surprise was the small savings credited to "shopping for better prices," which may be interpreted many ways. Most logical was the reason that most purchases and services were unavailable in the rural community and thus were not considered as a cash savings. Several indicated they spend more money because of the MCTS, however, the total for the estimated 900 bus-riding households was only $\$ 1,052$ or $\$ 1.17$ per household annually.

Other savings of value which were difficult to determine in monetary terms included such examples as the extra time taken by friends, relatives, family members, or others to transport the bus riders. Data obtained on "take time" given by the above persons for transporting, exclusive of taxi services, for all bus riders formerly using one of the above means amounted to 809 hours per month or 9,708 hours for the 130 households per year, or 67,208 hours for the 900 bus-riding households. No doubt a driver often had other uses for his or her time. Obviously, adjustments had to be made in driving schedules to accommodate the persons who now ride the bus. If the inconvenience and special trips

\section{Table 11}

Total Cash, Non-Cash Benefits Accruing to the 130 Bus-Riding Households and the 4,100 Households with Access to the MCTS, 1974.

\begin{tabular}{|c|c|c|c|}
\hline & \multicolumn{2}{|c|}{130 Households } & \multirow{2}{*}{$\begin{array}{l}900 \text { Households } \\
\text { Annual }\end{array}$} \\
\hline & Month & Annual & \\
\hline Total Cash Savings* & $\$ 2,986.44$ & $\$ 35,837$ & $\$ 248,196$ \\
\hline Salary Income ${ }^{* *}$ & $(1,277.20)$ & $(15,326)$ & $(106,143)$ \\
\hline Transportation savings ${ }^{* *}$ & $(1,666.18)$ & $(19,994)$ & $(138,472)$ \\
\hline Miscellaneous savings ${ }^{* *}$ & (43.06) & (517) & $(3,580)$ \\
\hline $\begin{array}{l}\text { Inputed Value of "take time" } \\
\text { of driver @ } \$ i .00 \text { per hour }\end{array}$ & 809.00 & 9.708 & 67,235 \\
\hline $\begin{array}{l}\text { Total benefits credited to } \\
\text { the MCTS }\end{array}$ & $\$ 3,795.44$ & $\$ 45,545$ & $\$ 315,431$ \\
\hline
\end{tabular}

*Savings not shown on Table 10 are those due to better shopping service, selling a car, and a miscellaneous group of reasons or $\$ \mathbf{4 3 . 0 6}$ per month for the $\mathbf{9 0 0}$ households.

**Included in Total Cash Savings.

***These benefits accrue to the bus riders and to those who would have provided the transportation in absence of the MCTS. Net disbenefits would go to the taxis, to those servicing the cars driven in absence of the MCTS, and to those losing the parking fee. 
were changed at an estimated opportunity cost of one dollar per hour for "take time," then the value credited to the MCTS would be $\$ 809.00$ per month for the 130 bus-riding households or $\$ 67,235$ for the 900 bus-riding households. Counting the cash and estimated non-cash benefits, the total credit accruing to the 4,100 households due to the MCTS was $\$ 315,431$ (Table 11 ).

\section{Distribution of Cash and Non-Cash Benefits}

The information in Table 11 reflects a redistribution of cash and non-cash benefits as a result of the MCTS. The number of persons or firms providing transportation prior to the MCTS was smaller than the number of households benefitting from the loss in cash income to these fewer persons or firms e.g. taxis, service stations, local stores, garages, and parking lots. This was estimated to be $\$ 142,053 .^{25}$

In terms of income distribution, a gain for some persons was loss for others. The estimated $\$ 142,053$ loss to the five types of enterprises represents a gain to an estimated 900 households. Since these households greatly exceed in numbers the firms or persons losing income, and obviously they are in lower income categories, they, therefore, would spend the bus-transportation savings on the basic needs and most likely at local stores. The likelihood of these savings being placed in saving accounts is remote. Therefore, the income distribution effects would accrue to households in the rural areas. Hence, most of the savings, or redistributed income would have its primary effect on the rural economy.

The salaried income of households reporting no other means of transportation has many ramifications. The income was taken to rural areas; much of it was probably spent in the rural areas, and since many were part-time employees the income may have substituted for public assistance payments. No data on these secondary and indirect effects on the local economy were obtained. Unless the proportions were large, such data would be difficult to obtain.

The MCTS is a business enterprise. As such it receives income from fares and a subsidy which it expends for salaries, fuel, and replacement parts. At least the salaries are spent in the Morgantown vicinity. Also, it pays local taxes on the fuel and replacement parts as does a private business. The subsidy amounted to $\$ 55,000$ and came from Revenue Sharing funds. ${ }^{26}$

\section{Cash Basis on a Comparison}

When all costs, capital and operating, and income from fares are considered (Table 8), and when credit is given for the cash savings to the passengers and also

${ }^{25} \$ 248,196$ less $\$ 106,143$.

${ }^{26}$ The $\$ 65,516$ shown in Tables 8 and 12 includes the amortized overhead. The $\$ 55,000$ was the public cash subsidy in 1974. 
for the income to persons who otherwise would not have the means for transportation (Table 11), the realized cash savings to the bus-riding households was $\$ 3.79$ for each dollar of public money spent (see Table 12).

As indicated earlier, more than one-half of the cash savings and income is in effect a sharing of the prior cash income of taxis, gasoline stations, garages, and parking lots with the 900 rural households.

An estimated 35 persons without other means of transportation earned an average of $\$ 3,060$ per year or a total of $\$ 106,143$ in 1974 . For each dollar of public money spent on the MCTS, \$1.62 was realized in the rural areas as salaried income (see Table 13). By this comparison the social value of employing 35 persons otherwise without transportation exceeds the public fund subsidy. 27

\section{Table 12}

\section{Cash Savings and Income Realized from Public Fund Support to MCTS.}

\begin{tabular}{lr} 
Item & Quantity \\
\hline $\begin{array}{l}\text { Amortized and operating public fund input (Table 5) } \\
\text { Total cash savings to passengers and credited salary } \\
\text { income (Table 10) }\end{array}$ & $\$ 65,516.00$ \\
$\begin{array}{l}\text { Total savings and income returned for each dollar of } \\
\text { public funds expended }\end{array}$ & $\$ 248,196.00$ \\
\hline
\end{tabular}

${ }^{*}$ Assumes public funds are used to offset the loss.

\section{Table 13}

Additional Salary Income Realized in Rural Areas Credited to Public Fund Support of MCTS.

\begin{tabular}{lc}
\hline Item & Quantity \\
\hline $\begin{array}{l}\text { Amortized and operating public fund input-annualized } \\
\text { Total additional salary income to rural areas (Table 10) }\end{array}$ & $\$ 65,516.00$ \\
Total income added to rural areas for each dollar of public & $\$ 106,143.00$ \\
funds & 1.62 \\
\hline
\end{tabular}

\footnotetext{
${ }^{27}$ Not known is whether the 35 persons would have had other employment. Doubtless some could have and also some would have had to depend on public assistance.
} 


\section{Comparison When "Take Time" Is Valued}

If one concedes that the reduction in "take time" because of the MCTS has monetary value, then the data, when all credits are assigned, presents yet another view, as shown in Table 14. Benefits of some monetary value beyond just cash accrue to MCTS when the "take time" by a friend, relative, or family member transports those needing transportation. Assuming that the "take time" has opportunity value of one dollar per hour, a total \$67,235 (Table 11) was gained in addition to the cash savings and income. Thus, the total annual worth of the MCTS was $\$ 315,431$ or $\$ 4.81$ for each dollar of public funds expended (see Table 14).

The cash savings and the salaried income credited to the MCTS obviously contribute to an improved income distribution among the county residents, more income to the rural areas, and a higher multiplier impact on the county's economy.

Three other indirect benefits were mentioned by the respondents, but not valued in monetary terms-saved time and energy for the person riding the bus, provided for improved health care, and eliminated dependency on someone to transport them, or as stated by many, "freedom to go to Morgantown and vicinity as I desire."

\section{COST-BENEFIT ANALYSIS}

Cost-benefit analysis differs from the standard profit and less accounting as shown in Table 8 in that it provides a method of accounting for the economic and social benefits and costs to the economy of the area over some predetermined period of time. In cost-benefit analysis, not only is the cash flow esti: mated over the life of the project by individual years, but also the social benefits and social costs are estimated. This type of analysis reflects to whom the benefits are distributed, as well as drawing attention to the time-value of money.

An accepted social rate of return (opportunity cost in other projects), 15 per cent, was used as the percentage discount rate to determine the present worth of

\section{Table 14}

\section{Cash Savings, Salaried Income, and Value of "Take Time" Realized from Public Funds Support of MCTS.}

Item

Quantity

Amortized and operating fund input-annualized

$\$ 65,516.00$

Total net benefits credited to the MCTS (Table 10)

$\$ 315,431.00$

Total savings, salaried income, and value of "take time"

for each dollar of public funds expended 
the project. Tables 11 and 8, with some adjustment, provide most of the information for the cost-benefit analysis. In this sense the welfare aspects of a public investment are evaluated and included in the analysis. Therefore, such an analysis responds to a different question(s) than would an accountant of a private enterprise. In other words, the benefits and costs, to the extent they can be measured, as they impact on society as a whole are considered. Hence, the analysis utilizes less precise data as means of including an estimate of social benefits as well as social costs.

Because decisions made today must anticipate future values and future costs, discounting is used to determine the value today of future income earned or money expended. A minimum acceptable rate of social return on public investment is calculated to be about 15 per cent, therefore, all future costs and benefits are discounted at that rate. Thus, to be worthy of consideration the social return for a dollar expended must be equal to or greater than 15 per cent.

Logically, public officials responsible for allocating public funds are guided by the principle of maximizing social benefits while minimizing social costs. Cost-benefit analysis is a valuable tool for their use as decision-makers.

A cost-benefit analysis for the MCTS is shown in Table 15. Details are shown in Appendix I.

The present value of measurable social benefits for the MCTS at a 15 per cent -iscount rate over an anticipated seven-year span was calculated to be $\$ 1,529,928$, while the present value of the anticipated social costs was calculated to be $\$ 518,096$, thus a cost-benefit ratio of 2.95 . Interpreted, this ratio means that assuming the minimum acceptable rate of social return would be 15 per cent, then for each public dollar expended over the seven-year span beyond the 15 per cent level $\$ 2.95$ would result as added social benefits discounted to the present year.

Another way to view the cost-benefit analysis is to add the present value of the net benefits over the seven-year span. This amounted to $\$ 1,012,016$ over and beyond the 15 per cent discount rate. Table 15 shows the present value of net benefits in the seventh year to be about half the present value for the second year. This phenomenon is due to the addition of the salvage value of the equipment to benefits for that year. More data from experience might show that the seven-year span for life of the vehicles is different than calculated here.

It may be argued that the benefits credited to the MCTS are too high. The cost-benefit analysis as shown in Table 15 does not account for the losses to the enterprises which prior to the establishment of MCTS were getting the money now credited as saved. In other words, does the amount saved add any value to the total product of the County's economy? While a precise answer cannot be provided, one can say, in economic terms, that the impact of the MCTS affected the distribution of income in that many more people benefited than lost. Generally this would result in greater purchasing power for those most needing 
Table 15

Social Rate of Return for MCTS for Seven Years, 1974 Data.*

\begin{tabular}{|c|c|c|c|c|c|c|c|}
\hline Item & 1 & 2 & 3 & 4 & 5 & 6 & 7 \\
\hline Benefits ${ }^{* *}-$ dollars & 366,000 & 366,000 & 366,000 & 366,000 & 366,000 & 366,000 & 387,600 \\
\hline $\begin{array}{l}\text { Present value } \\
@ 15 \%^{* * *}\end{array}$ & 318,237 & 276,696 & 208,986 & 240,645 & 181,902 & 158,112 & 145,350 \\
\hline $\begin{array}{l}\text { Total present value } \\
\text {-dollars }\end{array}$ & & & & & & & $1,529,928$ \\
\hline Costs $^{* * * *}$-dollars & 195,800 & 97,500 & 101,000 & 106,000 & 109,300 & 113,000 & 117,000 \\
\hline Present value @ 15\% & 170,248 & 73,719 & 66,407 & 60,600 & 54,322 & 48,816 & 43,984 \\
\hline Total present value & & & & & & & 518,096 \\
\hline $\begin{array}{l}\text { Ratio of costs } \\
\text { to benefits }\end{array}$ & & & & & & & 2.95 \\
\hline $\begin{array}{l}\text { Net benefits } \\
\text {-dollars }\end{array}$ & 170,200 & 268,500 & 265,000 & 260,000 & 256,700 & 253,000 & 270,600 \\
\hline Present value @ 15\% & 147,989 & 202,986 & 174,231 & 148,460 & 127,579 & 109,296 & 101,475 \\
\hline $\begin{array}{l}\text { Total present } \\
\text { value }- \text { dollars }\end{array}$ & & & & & & & $1,012,016$ \\
\hline
\end{tabular}

* Data assume constant benefits and costs, except for increasing costs of upkeep and maintenance of vehicles. See appendix for details.

* * Includes cash savings to those riding the bus compared to costs prior to establishing bus; salaried income to persons stating they had no means of transportation; salvage value at end of seven years, and estimated dollar value of time saved by friends, relatives, or members of family who formerly transported them as needed. Not counted are health benefits, freedom to go when one pleases, reduced stress, and other expressed benefits.

***The discount rate of 15 per cent is assumed to be a minimum acceptable social rate of return, or the opportunity cost of capital in other projects.

****Includes original investment in rolling equipment, rent for garage, repairs and maintenanc fuel which would be negligible. 
public transportation. One can also note that 35 persons were employed in Morgantown, which was credited to the MCTS as one may assume that similiar employment was not available locally. One can also note the value of time taken by family members of a household, relations, or friends to transport those unable to transport themselves. In addition to the measurable social benefits and costs, there are those that are not measurable, such as freedom to go and return as one desires or to offset loneliness with a trip to visit friends.

The cost-benefit analysis as presented rests on the assumptions that private enterprise could not provide a similiar service, as has been proven in this County and elsewhere with similar characteristics.

\section{PROSPECTIVE ROUTES NOT NOW SERVED}

Visual inspection of the highway map revealed sufficient residences on four possible extensions of existing bus routes to justify providing the service. All four were in the western part of the county. 28

Fifty-one households were randomly sampled to determine the interest and value of extending the bus service on four routes. Thirty per cent of the household members were over 50 years of age. This is about the same in that age caterory as in the sample along the established bus routes.

The following information was obtained by traveling the roads and counting the homes.

Of the 51 households sampled, 57 per cent reported annual incomes of less than $\$ 10,000$. This compares with 77 per cent of the 529 households sampled along the present bus routes. Twenty-eight of the 51 households indicated that one or more members of the households would ride the bus an average of 5.92 times each month if the service was available. Studies made in other regions on expectations show that they are higher than reality, because the schedules and need do not necessarily coincide.

Of the $\mathbf{5 1}$ households sampled, 96 per cent stated that it was appropriate to use public funds for the bus service, even though the service was unavailable to them. The main reason given was the service was needed by senior citizens. The distance from Morgantown, $\mathbf{4 5}$ miles for round trip, and the resulting isolation or the burden of a member or relative transporting their elders would lend emphasis to the high rate of approval.

\section{CONCLUSIONS}

The stated purpose and objectives of the study were realized through personal interviews with 592 households located within one-half mile of seven bus routes;

\footnotetext{
${ }^{28}$ Wadestown to Blacksville, Daybrook to West Virginia Highway 7, Jakes Run to West Virginia Highway 7, and Hagans to Crown. For the County map, see Figure 2.
} 


\section{Table 16}

Service of Prospective Riders Expressed in Square Miles, Number of Households, and Estimated Persons per Square Mile, 1974.

\begin{tabular}{|c|c|c|c|}
\hline Route & $\begin{array}{l}\text { Square } \\
\text { Miles }\end{array}$ & $\begin{array}{l}\text { Number } \\
\text { Households }\end{array}$ & $\begin{array}{l}\text { Estimated Persons } \\
\text { per Square Mile* }\end{array}$ \\
\hline \multicolumn{4}{|l|}{ Wadestown to } \\
\hline Blacksville & 5.0 & 154 & 101 \\
\hline \multicolumn{4}{|l|}{ Daybrook to WV } \\
\hline \multicolumn{4}{|l|}{ Highway 7 (27 } \\
\hline \multicolumn{4}{|l|}{ intersects 25 to 33} \\
\hline to 7$)$ & 6.0 & 195 & 106 \\
\hline \multicolumn{4}{|l|}{ Jakes Run to WV } \\
\hline \multicolumn{4}{|l|}{ Highway 7 (27 to 29} \\
\hline to 7$)$ & 3.75 & 135 & 118 \\
\hline \multicolumn{4}{|l|}{ Hagans to Cromın } \\
\hline \multicolumn{4}{|l|}{ (37 to 37 to } \\
\hline \multicolumn{4}{|l|}{ Crown where 26} \\
\hline intersects 37) & 3.0 & 65 & 71 \\
\hline Total and Averages & 17.75 & 545 & 101 \\
\hline
\end{tabular}

*Estimated at 3.28 persons per household as determined by the sample.

and through interviews with the Commissioners of Monongalia County, and their staff members.

The sampled 592 households were found to be fairly representative of all county households, with Morgantown omitted.

The cost of operating the MCTS appears high when compared with other selected passenger transportation systems established for the low income households and elderly persons. Whereas other systems estimated total costs including overhead to be a maximum of 32 cents per vehicle mile in 1968, the comparable cost for the MCTS was 66 cents in 1974. Increasing costs over the six-year span, and the costs of trial and error of learning, if they were known, would narrow the gap.

The most obvious value of the MCTS was its impact on income redistribution to households in rural areas. It was done in two ways (1) 900 households had cash savings by riding the MCTS which otherwise would have gone to a fewer number of private service enterprises, thus enhancing their income and probably resulting in a higher multiplier factor; and (2) an estimated 35 rural residents were able to be employed full or part time. This resulted in a money flow to rural areas estimated to be $\$ 106,143$ in 1974. 
Expenditure of public revenues for this rural transportation system appears well justified when the MCTS is credited with the cash savings and salaried income to the riders, compared with the costs of the means utilized prior to establishment of the MCTS. The realized cash savings and income to the busriding households was $\$ 2.89$ for each dollar of public revenue spent, including the annualized capital costs.

The MCTS also showed positive social benefits when evaluated over a sevenyear future time span. Annual costs and benefits were discounted at 15 per cent and added to ascertain the present value. The value of the MCTS with costs and benefits discounted to the present over a future seven-year span was $\$ 1,012,015$, or a cost-benefit ratio of $\$ 2.95$ benefit for each dollar of public revenue support.

It is doubtful if a privately owned and operated transportation system could succeed in the forseeable future, given the cost, income, population density, and fuel availability situation as it existed in 1974 .

With population density, income levels, other transportation costs, and age distribution characteristics similiar to Monongalia County it is likely that about one-half the cnerating cost and all of the capital cost would rely on public revenue sources. If the annual county budget remains essentially the same over future years, and allowing for normal increases and decreases, an external source will be a most likely requirement to cover the first and reoccurring capital costs.

Age distribution, household income levels, population density along possible bus routes, and distance from the main urban center are the principal variables affecting the number of persons who will regularly ride the bus in deference to other transportation means. The exceptions to these variables would be the high cost of auto operation, or limited availability of fuel for self-driven vehicles.

A severe gasoline shortage would sharply increase the ridership as was clearly demonstrated in February, 1974, when the number of riders increased 59 per cent in the one week when fuel was in short supply.

The study showed clearly that persons over 50 years of age are the principal source of passengers. Sixty-two per cent of the persons actually riding the bus were over 50 years of age compared to 29 per cent of all sampled houeholds. Income levels did not show up as important to bus ridership as expected although the data show a positive relationship between increasing age and lower income levels.

Those living the farthest from Morgantown had the highest percentage ridership. The most logical reason for this lies in the fewer opportunities to ride with someone because of lower population density.

Public support for the use of tax revenues for subsidizing a rural transportation system is likely to be exceptionally strong if the system provides a needed service to the elderly, the handicapped, and low income households.

A sample survey of the important variables affecting ridership is advisable prior to establishment of a passenger transportation system. Schedule $1 \mathrm{~A}$ (see 
Appendix) may be used to randomly sample $15-20$ per cent of the households along proposed routes. It is not likely that households living more than one-half mile from a proposed route will utilize the bus, especially if the potential riders are elderly. A commuter system consisting of local volunteers using lowoperating cost vehicles is a practical possibility for service to central places off the bus route and for isolated households.

\section{BIBLIOGRAPHY}

Dale Colyer. West Virginia Employment: By Industry Category. RM 13, Agricultural Economics. (Mimeo.) West Virginia University, 1973.

E. J. Mishan. Cost-Benefit Analysis. Praeger Publishers, 1971.

Issac Shafran. The Relationship Between the Structure of the Transportation Network and the Economic Development of West Virginia. Office of Research and Development, West Virginia University, Research Series 10. March, 1969.

U.S. Congress. Senate. Committee on Agriculture and Forestry. Transportation in Rural America Part I. Prepared by Economic Research Service, USDA. Gov. Printing Office. February 10, 1975.

U.S. Congress. Rural Development Act of 1972. Public Law 92-419. 92nd Congress. H.R. 12931. Gov. Printing Office. August 30, 1972.

U.S. Congress. Conference Report. The Federal-Aid Highway Act of 1973. 93rd Congress, 1st Session. Gov. Printing Office.

U.S. Congress. Senate. Committee on Agriculture and Forestry. Prelude to Legislation to Solve the Growing Crisis in Rural America: Part I Transportation in Rural America. Committee Print. Gov. Printing Office, 1975.

U.S. Congress. The State and Local Fiscal Assistance Act of 1972. Public Law 92-512. Gov. Printing Office.

U.S. Department of Commerce. Bureau of the Census. Current Population Reports, 1970. Series P-23, No. 28. Gov. Printing Office.

U.S. Department of Commerce. Bureau of the Census. General Population Characteristics West Virginia. 1970.

Secretary of Transportation. The Office of Policy and Plans Development. Rural Transit Operations and Management. A Mimeo. report, Washington, D.C. Estimated 1972 or 1973.

U.S. Department of Transportation. Bureau of Public Roads. The Transportation Needs of the Rural Poor. Research and Development Report. Washington, D.C., December, 1969.

West Virginia Department of Highways. General Highway Map, Monongalia County, West Virginia. January 1, 1972.

Personal Interviews. Richard E. Davies, Monongalia County Commissioner; Fred Root, Supervisor, MCTS; and Barry Goldberg, Executive Assistant to Monongalia County Commission. 
APPENDIXES 


\section{Appendix I \\ Social Rate of Return for MCTS for Seven-Year Span - 1974 Base \\ Data in Constant Dollars}

\begin{tabular}{|c|c|c|c|c|c|c|c|}
\hline & \multicolumn{7}{|c|}{ Year } \\
\hline & 1 & 2 & 3 & 4 & 5 & 6 & 7 \\
\hline \multicolumn{8}{|l|}{ Benefits - dollars } \\
\hline Savings to rieders & 142,000 & 142,000 & 142,000 & 142,000 & 142,000 & 142,000 & 142,000 \\
\hline Salaries to riders ${ }^{*}$ & 106,000 & 106,000 & 106,000 & 106,000 & 106,000 & 106,000 & 106,000 \\
\hline Income from fares & 51,000 & 51,000 & 51,000 & 51,000 & 51,000 & 51,000 & 51,000 \\
\hline Salvage of vehicles & -- & -- & -- & -- & - & -- & 21,000 \\
\hline $\begin{array}{l}\text { Value of driver-time } \\
\text { saved }\end{array}$ & 67,000 & 67,000 & 67,000 & 67,000 & 67,000 & 67,000 & 67,000 \\
\hline Total-dollars & 366,000 & 366,000 & 366,000 & 366,000 & 366,000 & 366,000 & 387,000 \\
\hline \multicolumn{8}{|l|}{ Costs - dollars } \\
\hline Investments ${ }^{* *}$ & 101,300 & -- & -- & -- & -- & -- & -- \\
\hline $\begin{array}{l}\text { Rent } \\
\text { Parts and Main- }\end{array}$ & 3,000 & 3,000 & 3,000 & 3,000 & 3,000 & 3,000 & 3,000 \\
\hline tenance ${ }^{* * *}$ & 3,500 & 6,500 & 10,000 & 15,000 & 18,300 & 22,000 & 26,000 \\
\hline Regular operating ${ }^{* * *}$ & 88,000 & 88,000 & 88,000 & 88,000 & 88,000 & 88,000 & 88,000 \\
\hline Total - dollars & 195,000 & 97,500 & 101,000 & 106,000 & 109,300 & 113,000 & 117,000 \\
\hline Net Benefits-dollars & 170,200 & 268,500 & 265,000 & 260,000 & 256,700 & 253,000 & 270,600 \\
\hline $\begin{array}{l}\text { Subsidy to run the } \\
\text { system }{ }^{* * * * *}\end{array}$ & 144,800 & 46,500 & 50,000 & 55,000 & 58,300 & 62,000 & 45,000 \\
\hline
\end{tabular}


*For only those without another means of transportation.

** Original rolling stock. All charged off in first year.

***Total cost of repairs, based upon other studies, over the normal life of a vehicle are about equal to the original cost. The total amount was charged at a constant rate of increase.

****From the actual expense data shown on Table 21 adjustments in annual cost were made because parts and main tenance and tools were included. The average of the 4 medium months over a 24-month span was taken to obtain a normal figure. Some unusual costs arose in study period because of the high requirement for replacement parts due to rough roads. With foreign-make vehicles, costs were considered excessive to the purposes of the study.

*****Total cost less income from fares. 


\section{Appendix II}

\section{STAR CITY}

7:40 a m.--Lv. Morgantown for Star C1ty, Suncrest National Bank, University and General Hospitals, Chestnut Ridge Rd., Point Marion Rd., Canyon to Tyrone Rd. on Cheat Rd. Return Cheat Rd. to Mileground to Morgantown.

9:00 a.m., 10:00 a.m., 11:00 a.m., 12:00 noon, 1:00 p.m., 2:00 p.m., 3:00 p.m., 4:00 p.m.-Lv. Morgantown, arr. Hills 5 min. after the hour, Star City Town Hall $10 \mathrm{~min}$. after the hr., and University Hospital $15 \mathrm{~min}$. after the hour. (10:00 a.m., 12:00 noon, and 12:00 p.m. buses continue to Chestnut Ridge Rd. to Stewart St. Lv. Stewart St. 20 min. after the hr. Return via Stewart St., Willowdale Rd., University Hospital.) (Lv. University Hospital 9:30 a.m. 10:30 a.m., 11:30 a.m., 12:30 p.m., 2:30 p.m. 3:30 p.m., and 4:30 p.m., arr. at Star City Town Hall' 25 til the hour. Arr. Hills 20 til the hour. Travel Monongahela Blvd., Beechurst Ave. to Morgantown.)

5:10 p.m. Lv. Morgantown for Hills, Star City, Suncrest National Bank, University and General hospitals, Chestnut Ridge Rd., Point Marion Rd., Canyon to Tyrone Rd., Cheat Rd. Return Cheat Rd. to Mileground to Morgantown.

\section{CASSVILLE}

5:30 a,m,--Lv, Morgantown, Arr, Cassville 6:00 a.m. Lv. Cassville 6:00 a.m., arr. Morgantown 6:25 a.m. (Continues to Evantsdale Campus and University and General hospitals.)

6:30 a.m.--Lv. Walnut Street PRT for University and General hospitals, Star City, arr. Cassville 7:00 a.m.

7:00 a.m.--Lv. Cassville. Arr. Morgantown via Morgan Heights $7: 40$ a.m.

$8: 00,9: 00,10: 00,11: 00$ a.m.--Lv. Morgantown Arr. Cassville $30 \mathrm{~min}$. after the $\mathrm{hr}$.

$8: 30,9: 30,10: 30,11: 30$ a.m.--Lv. Cassville. Arr. Morgantown $5 \mathrm{~min}$. before the hr.

$1: 00,2: 00,3: 00,4: 00,5: 10$ p.m.--Lv. Morgantown. Arr. Cassville $20 \mathrm{~min}$. after the $\mathrm{hr}$.

$1: 30,2: 30,3: 30,4: 30,5: 30$ p.m.--Lv. Cassville. Arr. Morgantown $5 \mathrm{~min}$. before the $\mathrm{hr}$.

\section{To Cassville--}

Lv. Westover $10 \mathrm{~min}$. after departure.

Lv. Granville $15 \mathrm{~min}$. after departure.

Lv. Osage $20 \mathrm{~min}$. after departure.

To Morgantown--

Lv. Osage $10 \mathrm{~min}$. after departure.

Lv. Granville $15 \mathrm{~min}$. after departure.

Lv. Westover $20 \mathrm{~min}$. after departure.

\section{OVER CHEAT}

(Brookhaven, Tyrone, Imperial Woods, Canyon, Easton, Mileground, and Cheat Rd. to State Line) 8:00 a.m.--Lv. State Line Over Cheat to Tyrone Rd., Dellslow, Richard, and Brookhaven. Arr. Morgantown $8: 45 \mathrm{a} . \mathrm{m}$.

$9: 30$ a.m.--Lv. Morgantown. Arr. Brookhaven 9:35 a.m., Richard 9:38 a.m., Dellslow 9:40 a.m., Field Park and Tyrone Rd. 9:45 a.m. Avery Rd, 9:50 a,m, and Rockley Rd, 9:55 a.m. Turn at Rockley Rd. and return to Imperial Woods Rd. Arr. Imperial Woods Rd, and Avery Rd. 10:00 a.m., Cheat Rd. 10:05 a.m., Canyon 10:10 a.m., Rt. 119 10:12 a.m., Mileground
10:15 a.m., Morgantown 10:20 a.m.

11:30 a.m.--Lv. Morgantown for Mileground, Easton, Pierpont to State Line. Lv. State Line 12:00 noon for Tyrone, Dellslow, Richard, Brookhaven. Arr. Morgantown $12: 45 \mathrm{p} . \mathrm{m}$.

2:00 p.m. -- Lv. Morgantown. Arr. Brookhaven 2:05 p.m., Richard 2:08 p.m. Dellslow 2:10 p.m., Field Park and Tyrone Rd. 2:15 p.m., Avery Rd. 2:20 p.m., Rockley Rd. 2:25 p.m. Return to Imperial Woods Rd. and arr. Imperial Woods and Avery Rd. 2:30 p.m., Cheat Rd. 2:35 p.m., Canyon 2:40 p.m., Rt. 119 2:42 p.m., Mileground 2:45 p.m., Morgantown 2:50 p.m.

4:00 p.m.--Lv. Morgantown for Brookhaven, Richard, Dellslow, Tyrone Rd., Cheat Rd., Easton, Mileground, and return. Arr. Morgantown 4:45 p.m.

5:10 p.m.--Lv. Morgantown for Brookhaven, Richard, Dellslow, Tyrone Rd., Over Cheat to State Line.

\section{CROWN}

(Morgan Helghts, Booth, Naticnal, Everettville, Arnettsville, Crown)

7:25 a.m.--Lv. Morgan Heights, Arr. Morgantown $7: 40 \mathrm{a} \cdot \mathrm{m}$.

7:30 a.m.--Lv. Morgantown, travel by Fairmont Rd. Arr. Crown 8:00 a.m.

8:00 a.m.--Lv. Crown for Arnettsville, Everettville, National, Booth. Arr. Morgantown $8: 45$ a.m.

1:00 p.m.--Lv. Morgantown for Booth, National, Everettville. Lv. Everettville 1:30 p.m., National, Booth. Arr. Morgantown 2:00 p.m.

3:40 p.m.--Lv. Morgantown for Morgan Heights, and return. Arr. Morgantown 4:05 p.m.

$5: 10$ p.m.--Lv. Morgantown for Morgan Heights, Booth, National, Everettville. Arr. Crown 5:50 p.m. Lv. Crown 5:50 p.m., travel by Fairmont Rd., arr. Morgantown 6:20 p.m.

\section{GRAFTON AND FAIRMONT ROADS}

(Wednesday and Saturday only)

10:30 a.m.--Lv. Morgantown. Arr. Fairmont and Halleck Rd. 10:50 a.m., Grafton and Halleck Rd. 11:10 a.m., Morgantown, 11:30.

$3: 30$ p.m.--Lv. Morgantown. Arr. Grafton and Halleck Rd. 3:50 p.m., Fairmont and Halleck Rd. 4:10 p.m., Morgantown 4:30 p.m.

\section{BLACKSVILLE}

8:30 a.m.--Lv. Morgantown. Arr. Cassville $8: 45$ a.m., Core $8: 50$ a.m., Pentress 8:55 a.m., Blacksville 9:00 a.m.

9:00 a.m.--Lv. Blacksville. Arr. Pentress 9:05 a.m., Core 9:10 a.m., Cassville 9:15 a.m. Morgantown 9:30 a.m.

2:00 p.m.--Lv. Morgantown. Arr. Cassville 2:15 p.m., Core 2:20 p.m., Pentress 2:25 p.m., Blacksville 2:30 p.m.

2:30 p.m.--Lv. Blacksville. Arr. Pentress 2:35 p.m., Core 2:40 p.m., Cassville 2:45 p.m., Morgantown 3:00 p.m.

MCTS Bus Schedule

May 1974 


\section{Appendix III \\ Monongalia County Public Transportation Study \\ PART I}

\section{Background Data}

1. Name and number

2. Sex: $F \quad M$

3. Position in the HH: Husband Wife Son Daughter Relative

4. Ages in the $\mathrm{HH}$, (Number in each age grouping): $-1-5(), 6-14()$, 15-18 ( ), 19-24 ( ), 25-34 ( ), 35-49 ( ), 50-64 ( ), 65-over ().

5. Note: Underline the age group for the respondent.

6. Total number in the $\mathrm{HH}$

\section{Income level}

a) Check the appropriate household income from all sources for one year.

$\begin{array}{lll}\text { a-1) less than } \$ 1000 & ( \\ \text { a-2) } \$ 1000-4999 & ( \\ a-3) \$ 5000-9999 & ( \\ \text { a-4) } \$ 10000-14999 & ( \\ \text { a-5) over } \$ 15000 & (\quad)\end{array}$

8. Primary source of family income: Farm ( ), other private sources ( ), wages or salaries ( ), social security ( ), public assistance or welfare ( ), retirement other than social security (), other ( ), specify:

9. Distance to bus route from your house: yards or miles.

10. How many vehicles operated by your household members:

11. Do you ride the county bus: yes no ?

12. Do any other members of your $\mathrm{HH}$ ride the bus: yes no ?

13. If the answers to questions 11 and 12 are no, then this question: "Are there any reason(s) why you do not use the county bus service?"

14. Do you know of any circumstances which if they existed, you would ride the county bus service?

Appendix III Schedule used for all households interviewed. 
15. In your opinion is the county bus service very important, important, not important to your community? Reason for answer

16. Do you think it is appropriate for public funds to be spent on providing bus service to non-metropolitan residents? Yes no Give reasons

17. May I have the name (or location of the dwelling) of two persons in different households living nearest to your home.

Name (or location)

18. The county bus service would be more valuable to your household if:

Note to enumerator: If answers to questions $11 \& 12$ are No, then express your appreciation for the interview and dismiss yourself. However, complete Part III afterwards. Obtain a completed schedule from one of the two suggested riders. Take the nearest first. If the answers to either 11 or 12 are Yes, then go to Part II.

Date

Enumerator 


\section{Monongalia County Public Transportation Study* PART IA}

1. Name and number

2. Sex: $F \quad M$

3. Position in the HH: Husband Wife Son Daughter Relative

4. Ages in the $\mathrm{HH}$, (number in each age grouping): $1-5($ ), 6-14 (), 15-18 ( ), 19-24 ( ), 25-34 ( ), 35-49 (),50-64 ( ), 65-over ( ).

5. Note: Underline the age group for the respondent.

6. Total number in the $\mathrm{HH}$

7. Would a member of your $\mathrm{HH}$ ride the $\mathrm{CBS}$ if a route was established within one-half $(1 / 2)$ mile or closer: Yes No ?

8. If the answer to No. 6 is yes:

(a) How many trips per month would all members of your $\mathrm{HH}$ ride the CBS? No. Members Total No. trips per month

(b) Distance to Morgantown miles round trip.

(c) What means of transportation do you use now? c-1 Take a taxi Cost per round trip

c-2 A friend or relative takes (us) (me) . Time per RT $\min$.

Do you pay anything to your friend or relative: Yes No ?

Amount per month, trip \$ ?

Does your friend or relative take other people too: Yes No ?

c-3 I would drive a car: Yes No ?

Why would you prefer the bus to your car

c-4 Number of trips now to Morgantown and vicinity

*Appendix IV was used for the possible routes not now being served. 
9. If the answer to No. 6 is No:

(a) How many vehicles operated by your household

(b) Do you use your vehicles to take persons not from your household to Morgantown and vicinity: Yes No ? Usually is the trip when you are going anyway: Yes No ?

b-1 If the answer to $9 b$ is yes:

No. persons taken

No. trips per month when person

other than $\mathrm{HH}$ are taken

(c) What is your estimate of the cost of an automobile trip to Morgantown and vicinity? Include total cost plus parking fees Cost per mile $\$$ or cost per round trip \$

10. Income level

(a) Check the appropriate household income from all sources for one year.

$\begin{array}{lll}\text { a-1) less that } \$ 1,000 & \text { ) } \\ \text { a-2) } \$ 1,000-4,999 & \text {; } \\ \text { a-3) } \$ 5,000-9,999 & ( \\ \text { a-4) } \$ 10,000-14,999 & \text {; } \\ \text { a-5) over } \$ 15,000 & \text { ( ) }\end{array}$

11. Primary source of family income: Farm ( ), other private sources ( ), wages or salaries ( ), social security ( ), public assistance or welfare ( ), retirement other than social security (), other ( ) specify:

12. Do you think it is appropriate for public funds to be spent on providing bus service to non-metropolitan residents? Yes No. Give reasons

Enumerator

Date 


\section{Appendix V}

\section{Public Transportation Study \\ PART II}

Name \& Number

1. Frequency of bus trips

\begin{tabular}{|c|c|c|c|c|}
\hline $\begin{array}{c}\text { Age } \\
\text { group }\end{array}$ & $\begin{array}{c}\text { Frequency- } \\
\text { no. wk. or mo. } \\
\text { A }\end{array}$ & $\begin{array}{c}\text { Time period: } \\
\mathrm{t}_{1} \text { to } \mathrm{t}_{2} \\
\mathrm{~B}\end{array}$ & $\begin{array}{c}\text { Total number } \\
\text { of trips } \\
\mathrm{A} \times \mathrm{B}=\end{array}$ & \\
\hline & & & & \\
\hline & & & & \\
\hline & & & & \\
\hline & & & & \\
\hline
\end{tabular}

E. Notes:

2. Purpose

a) Employed in Morgantown vicinity:

b) Attend to legal matters:

c) Attend to banking or financing services

d) Purchase personal or household necessities-e.g. shopping:

e) Get welfare check, food stamps, other public assistance:

f) Obtain medical, dental, or other health services:

g) For recreation:

h) Visit relatives or friends:

i) Other (sp зcify):

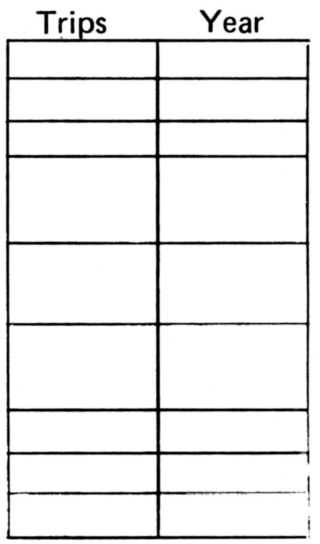

\section{Total}

Note: Totals for $Q_{1} \& Q_{2}$ should be same.

E. Notes: 


\section{Values of Service:}

We wish to find out the value of the service to the households that ride the bus. Some value is found in savings of money to the rider. There is also the value of convenience, that is, it saves time for some member of the household. First, let's try to determine its money value to the household.

If the bus service was not available to provide the transportation needs of the household, indicate the means that would be used by your household.

a-1) Situation one: Over the time period shown in 0.1 , the respondent would have had to pay for transportation to a taxi, a local person, or someone:yes, no.

\begin{tabular}{|c|l|c|c|c|c|c|c|c|}
\cline { 5 - 8 } & \multicolumn{2}{c|}{ Bus Service } & & \\
\hline $\begin{array}{c}\text { Time } \\
\text { Period }\end{array}$ & Purpose & $\begin{array}{c}\text { No. } \\
\text { trips }\end{array}$ & $\begin{array}{c}\text { Cost/ } \\
\text { R. Trip }\end{array}$ & $\begin{array}{c}\text { Total } \\
\text { Cost }\end{array}$ & $\begin{array}{c}\text { No. } \\
\text { Trips }\end{array}$ & $\begin{array}{l}\text { Fare/ } \\
\text { R. Trip }\end{array}$ & $\begin{array}{l}\text { Total } \\
\text { Cost }\end{array}$ & \\
\hline & & & & & & & & \\
\hline & & & & & & & & \\
\hline
\end{tabular}

E. Notes:

Appendix V Schedule used for bus-riding households

a-2) Situation two: A friend or relative not in the household provided transportation at no cost.

\begin{tabular}{|l|l|l|l|l|l|l|l|}
\hline $\begin{array}{l}\text { Time } \\
\text { Period }\end{array}$ & Purpose & $\begin{array}{l}\text { No. } \\
\text { Trips }\end{array}$ & $\begin{array}{l}\text { Miles/ } \\
\text { Trip }\end{array}$ & $\begin{array}{l}\text { Total } \\
\text { Miles }\end{array}$ & $\begin{array}{l}\text { Probable } \\
\text { Cost }\end{array}$ & $\begin{array}{l}\text { Hours/ } \\
\text { Trip }\end{array}$ & $\begin{array}{l}\text { Total } \\
\text { Hours }\end{array}$ \\
\hline & & & & & & & \\
\hline & & & & & & & \\
\hline
\end{tabular}

Bus Service

\begin{tabular}{|l|l|l|l|l|l|l|l|}
\hline $\begin{array}{l}\text { Time } \\
\text { Period }\end{array}$ & $\begin{array}{l}\text { No. } \\
\text { Trips }\end{array}$ & $\begin{array}{l}\text { Bus fare/ } \\
\text { R. Trip }\end{array}$ & $\begin{array}{l}\text { Total } \\
\text { Cost }\end{array}$ & & & & \\
\hline & & & & & & & \\
\hline & & & & & & & \\
\hline
\end{tabular}

E. Notes: 
a-3) Situation three: One member of the household would have transported another member of the $\mathrm{HH}$.

\begin{tabular}{|l|l|l|l|l|l|l|l|}
\hline $\begin{array}{l}\text { Time } \\
\text { Period }\end{array}$ & Purpose & $\begin{array}{l}\text { No. } \\
\text { Trips }\end{array}$ & $\begin{array}{l}\text { Miles/ } \\
\text { Trip }\end{array}$ & $\begin{array}{l}\text { Total } \\
\text { Miles }\end{array}$ & $\begin{array}{l}\text { Probable } \\
\text { Cost }\end{array}$ & $\begin{array}{l}\text { Hours/ } \\
\text { Trip }\end{array}$ & $\begin{array}{l}\text { Total } \\
\text { Hours }\end{array}$ \\
\hline & & & & & & & \\
\hline & & & & & & & \\
\hline
\end{tabular}

Bus Service

\begin{tabular}{|l|l|l|l|l|l|l|l|}
\hline $\begin{array}{l}\text { Time } \\
\text { Period }\end{array}$ & $\begin{array}{l}\text { No. } \\
\text { Trips }\end{array}$ & $\begin{array}{l}\text { Bus fare/ } \\
\text { R. trip }\end{array}$ & $\begin{array}{l}\text { Total } \\
\text { Cost }\end{array}$ & & & & \\
\hline & & & & & & & \\
\hline & & & & & & & \\
\hline
\end{tabular}

E. Notes:

a-4) Situation four: Transportation would have been provided by some means other than a-1, a-2, or a-3.

\begin{tabular}{|l|l|l|l|l|l|l|l|}
\hline $\begin{array}{l}\text { Time } \\
\text { Period }\end{array}$ & Purpose & $\begin{array}{l}\text { No. } \\
\text { Trips }\end{array}$ & $\begin{array}{l}\text { Miles/ } \\
\text { Trip }\end{array}$ & $\begin{array}{l}\text { Total } \\
\text { Miles }\end{array}$ & $\begin{array}{l}\text { Probable } \\
\text { Cost }\end{array}$ & $\begin{array}{l}\text { Hours/ } \\
\text { Trip }\end{array}$ & $\begin{array}{l}\text { Total } \\
\text { Hours }\end{array}$ \\
\hline & & & & & & & \\
\hline & & & & & & & \\
\hline
\end{tabular}

Bus Service

\begin{tabular}{|l|l|l|l|l|l|l|l|}
\hline $\begin{array}{l}\text { Time } \\
\text { Period }\end{array}$ & $\begin{array}{l}\text { No. } \\
\text { Trips }\end{array}$ & $\begin{array}{l}\text { Bus fare/ } \\
\text { R. trip }\end{array}$ & $\begin{array}{l}\text { Total } \\
\text { Cost }\end{array}$ & & & & \\
\hline & & & & & & & \\
\hline & & & & & & & \\
\hline
\end{tabular}


b) Does the bus service make it possible for one or more members of the household to earn or receive money which would not be earned or received if the bus service did not operate:- yes, no?

\begin{tabular}{|l|l|l|l|l|}
\hline$t_{1}$ to $t_{2}$ & $t_{3}$ to $t_{4}$ & $\begin{array}{c}\text { Income } \\
A\end{array}$ & $\begin{array}{c}\text { Bus Fare } \\
\text { B }\end{array}$ & $\begin{array}{c}\text { Net Income } \\
\text { A minus } B\end{array}$ \\
\hline & & & & \\
\hline
\end{tabular}

E. Notes:

c) Does the bus service eliminate the need for (one or two) vehicles in the household:- yes, no? If the answer is yes, then:-

Miles not driven because of available bus service.

\begin{tabular}{|l|c|c|c|l|}
\hline$t_{1}$ to $t_{2}$ & $\begin{array}{c}\text { Miles "saved" } \\
\text { A }\end{array}$ & $\begin{array}{c}\text { Cost per mile } \\
\text { B }\end{array}$ & $\begin{array}{c}\text { Bus fare } \\
\text { C }\end{array}$ & $\begin{array}{l}\text { Savings from } t_{1} \text { tot }_{2} \\
\mathrm{~A} \times \mathrm{B}-\mathrm{C}=\end{array}$ \\
\hline & & & & $\$$ \\
\hline
\end{tabular}

E. Notes:

c-1) Respondent disposed of a vehicle or one was no longer available:- Yes, no. If yes, then:-

Miles not driven because of available bus service.

\begin{tabular}{|l|c|r|r|l|}
\hline$t_{1}$ to $t_{2}$ & $\begin{array}{c}\text { Miles "saved" } \\
\text { A }\end{array}$ & $\begin{array}{c}\text { Cost per mile } \\
\text { B }\end{array}$ & $\begin{array}{c}\text { Bus fare } \\
\text { C }\end{array}$ & $\begin{array}{l}\text { Savings from } t_{1} \text { to }_{2} \\
\text { A } \times \text { B }-C=~\end{array}$ \\
\hline & & & & $\$$ \\
\hline
\end{tabular}

E. Notes:

c-2) Respondent would have purchased a vehicle if the bus service did not exist.

\begin{tabular}{|c|c|c|c|l|}
\hline$t_{1}$ to $t_{2}$ & $\begin{array}{c}\text { Miles "saved" } \\
\text { A }\end{array}$ & $\begin{array}{c}\text { Cost per mile } \\
\text { B }\end{array}$ & $\begin{array}{c}\text { Bus fare } \\
\text { C }\end{array}$ & $\begin{array}{l}\text { Savings from } t_{1} \text { to } t_{2} \\
\text { A } \times \text { B }-C=~\end{array}$ \\
\hline & & & & \\
\hline
\end{tabular}

E. Notes: 
d) It is possible that because of the bus service you can save money by shopping for better prices or bargains. Is this true for this household:-

yes, no. If yes, then in what way and how much was saved by the $\mathrm{HH}$ ?

\begin{tabular}{|l|l|}
\hline Examples & Savings \\
\hline & \\
\hline & \\
\hline & \\
\hline & \\
\hline
\end{tabular}

E. Notes:

e) Are there other ways in which the bus service saves money to the household? yes, no. If yes, then:-

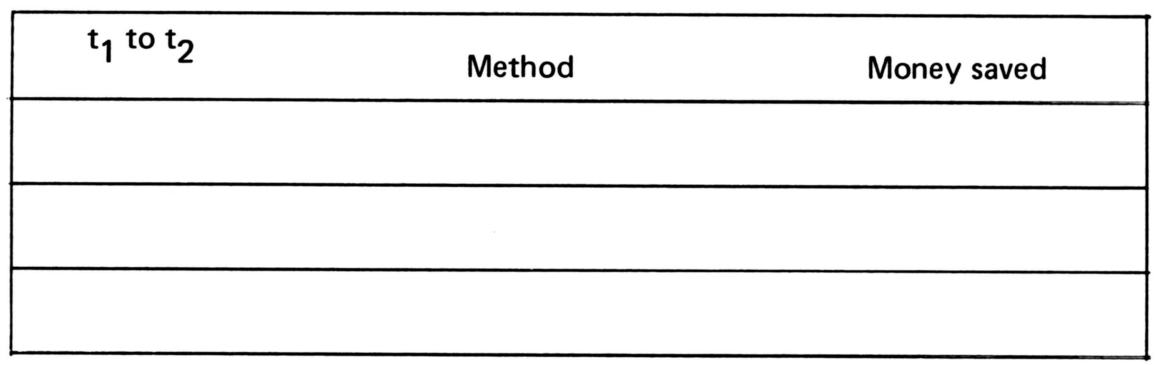

\section{E. Notes:}

f) If we add all the ways that the bus service saves money to the household we get a total of $\$$ Time period covered by this total

Note: Check this total with the respondent.

E. Notes: 
g) Perhaps the bus service has some values which are not expressed in money terms. Are there any to the $\mathrm{HH}$ :- yes, no. If so, then what are they?*

\begin{tabular}{lll}
\multicolumn{1}{c}{} & No. trips/year \\
\cline { 2 - 2 } & \\
\hline & \\
\hline & \\
\hline
\end{tabular}

*Examples: Can purchase items not available locally, can obtain medical or dental assistance when needed, can visit friends and relations as desired, and others.

E. Notes:

h) It is possible that because of the bus service this household now spends more money than if the service was not available. Is this so? yes, no.

If yes, then for what purposes was more money spent?

General Categories of Expense (same as Q 2)

Cost

\begin{tabular}{|r|l|}
\hline & \\
\hline & \\
\hline & \\
\hline & \\
\hline Total & \\
\hline
\end{tabular}

h-1) Were the above expenses essential:- yes, no? Percentage essential $?$ 
[Blank Page in Original Bulletin] 
[Blank Page in Original Bulletin] 